\title{
The impact of vitamin D pathway genetic variation and circulating 25-hydroxyvitamin D on cancer outcome: systematic review and meta-analysis
}

P G Vaughan-Shaw ${ }^{1}$, F O'Sullivan ${ }^{2}$, S M Farrington ${ }^{1}$, E Theodoratou ${ }^{1,3}$, H Campbell ${ }^{1,3}$, M G Dunlop ${ }^{1}$ and L Zgaga*,2

${ }^{1}$ MRC Human Genetics Unit, Institute of Genetics and Molecular Medicine, University of Edinburgh, Edinburgh EH42XU, UK; ${ }^{2}$ Department of Public Health and Primary Care, Trinity College Dublin, Dublin 24, Republic of Ireland and ${ }^{3}$ Centre for Population Health Sciences, University of Edinburgh, Edinburgh EH164UX, UK

Background: Vitamin $D$ has been linked with improved cancer outcome. This systematic review and meta-analysis investigates the relationship between cancer outcomes and both vitamin D-related genetic variation and circulating 25-hydroxyvitamin D (25OHD) concentration.

Methods: A systematic review and meta-analysis of papers until November 2016 on PubMed, EMBASE and Web of Science pertaining to association between circulating vitamin $D$ level, functionally relevant vitamin $D$ receptor genetic variants and variants within vitamin D pathway genes and cancer survival or disease progression was performed.

Results: A total of 44165 cases from 64 studies were included in meta-analyses. Higher 25OHD was associated with better overall survival (hazard ratio ( $\mathrm{HR}=0.74,95 \% \mathrm{Cl}$ : 0.66-0.82) and progression-free survival ( $\mathrm{HR}=0.84,95 \% \mathrm{Cl}$ : 0.77-0.91). The rs 1544410 (Bsml) variant was associated with overall survival ( $\mathrm{HR}=1.40,95 \% \mathrm{Cl}: 1.05-1.75)$ and rs7975232 (Apal) with progression-free survival $(\mathrm{HR}=1.29,95 \% \mathrm{Cl}: 1.02-1.56)$. The rs 2228570 (Fokl) variant was associated with overall survival in lung cancer patients ( $\mathrm{HR}=1.29$, $95 \% \mathrm{Cl}: 1.0-1.57)$, with a suggestive association across all cancers ( $\mathrm{HR}=1.26,95 \% \mathrm{Cl}: 0.96-1.56)$.

Conclusions: Higher 25OHD concentration is associated with better cancer outcome, and the observed association of functional variants in vitamin D pathway genes with outcome supports a causal link. This analysis provides powerful background rationale to instigate clinical trials to investigate the potential beneficial effect of vitamin $D$ in the context of stratification by genotype.

The importance of vitamin $\mathrm{D}$ for bone health is well established, but the role of vitamin $\mathrm{D}$ beyond the skeletal system has been under debate for decades (Theodoratou et al, 2014). In recent years, it has become apparent that the vitamin D receptor (VDR) is expressed in most cells, and that multiple tissues have the ability to convert the primary circulating form of vitamin $\mathrm{D}$ into the active form (Bouillon et al, 2013), implying that extra-skeletal effects of vitamin $\mathrm{D}$ are likely.
While typically thought of as 'vitamin', it may be more appropriate to regard the primary circulating form, 25-hydroxyvitamin D (25OHD), as a pre-hormone and the primary active form, 1,25-dihydroxyvitamin $\mathrm{D}\left(1,25(\mathrm{OH})_{2} \mathrm{D}\right)$, as a hormone. It has been previously recognised that mutations in genes involved in response to hormones, their metabolism or actions may affect the prognosis of disease and thus act as modifiers. Correspondingly, $1,25(\mathrm{OH})_{2} \mathrm{D}$ binds to the VDR (a ligand-dependent

*Correspondence: Dr L Zgaga; E-mail: zgagal@tcd.ie 
transcription factor) and polymorphisms in the $V D R$ gene have been shown to modify the activity of this VitD-VDR complex (Anderson et al, 2003): for example, rs11568820 is situated in the $V D R$ promoter region and can influence transcriptional activity (Yamamoto et al, 1999), while rs2228570 affects the translational start site (Uitterlinden et al, 2004). Therefore, it is hypothesised that not only vitamin D status but also expression and structure of $V D R$ determine molecular actions, and can potentially modify cancer risk and survival (Flugge et al, 2007; Li et al, 2007; Zgaga et al, 2014). The VitD-VDR complex has the ability to exert downstream biological effects; amongst others, it can regulate the expression of multiple target genes, including several with antitumour properties (Ramagopalan et al, 2010). Moreover, polymorphisms in the VDR gene have been linked to cancer risk, including prostate (Taylor et al, 1996), breast (Lowe et al, 2005), skin and bowel (Ingles et al, 2001; Xu et al, 2014; Serrano et al, 2016), and VDR expression has been linked to survival in prostate and breast cancer (Berger et al, 1991; Hendrickson et al, 2011; Ditsch et al, 2012). Unlike highly variable environmental exposures (sunlight, diet and supplements) or seasonally varying 25OHD levels (Kelly et al, 2015), genetic variants are constant, present since conception and cannot be modified by the disease; thereby removing reverse causation concerns.

Three aspects further strengthen the case for understanding the associations between vitamin $\mathrm{D}$ and cancer outcomes: first, cancer incidence and mortality are increasing (CRUK, 2015); second, vitamin $\mathrm{D}$ deficiency is common worldwide among otherwise healthy individuals (Holick, 2007; Zgaga et al, 2011), and particularly among cancer patients (Crew et al, 2009; Fakih et al, 2009; Shanafelt et al, 2011; Vrieling et al, 2011; Zgaga et al, 2014), and third, vitamin D deficiency is a modifiable risk factor; based on the studies that report an association between vitamin D deficiency and poorer cancers outcomes. Unsurprisingly, it has been proposed that vitamin $\mathrm{D}$ may have potential value as an adjuvant chemotherapeutic agent, particularly since vitamin D supplements are cheap, safe and readily available (Newton-Bishop et al, 2009, 2015; Drake et al, 2010; Hatse et al, 2012; Zgaga et al, 2014).

Here we present a systematic review and meta-analysis examining the role of vitamin $\mathrm{D}$ on cancer progression and survival. We conducted a comprehensive evaluation of the literature that examines the associations between cancer outcomes and genetic factors involved in the vitamin $\mathrm{D}$ pathway, in addition to circulating $25 \mathrm{OHD}$ concentration. Focus on vitamin D-related genetic variation allowed us to partially mitigate against potential confounding or reverse causation, biases that typically limit implications of findings from observational vitamin D studies.

\section{MATERIALS AND METHODS}

Literature search. We performed a systematic literature review and meta-analysis following PRISMA guidelines (Moher et al, 2009). The electronic databases PubMed (NCBI, 2015), EMBASE (EMBASE, 2015), and Web of Science (JISC, 2015) were searched up to week 3, November 2015. We searched for studies that examined the association between cancer outcomes and (i) measured vitamin D levels and (ii) genetic factors known to affect vitamin D metabolism or pathways. A list of search terms was compiled using a number of core papers in the field. For cancer outcomes, we included a combination of terms: cancer, neoplasm, malignant, malignancy with survival, outcome, prognosis, mortality, death, recurrence. For vitamin D levels, we included terms: 25-hydroxyvitamin D, calcidiol and 25OHD; for vitamin $\mathrm{D}$ receptor, and for commonly studied variants, we searched for: vitamin D receptor, $V D R$, rs1544410, BsmI, rs10735810, rs2228570, FokI, rs7975232, ApaI, rs11568820, Cdx-
2, rs2282679, rs12785878, rs10741657 and rs6013897. Finally, we also included variation in genes related to vitamin D synthesis, transport or metabolism: 1- $\alpha$-hydroxylase, CYP27B1, 25-hydroxylase, CYP2R1, 24-hydroxylase, CYP24A1, vitamin D binding protein, 27-hydroxlyase and CYP27A1. Genetic variants beyond those explicitly searched for were only included if previously shown to affect vitamin D metabolism. We considered all human research full text articles, with no restriction on language or article type. Bibliographies of retrieved papers and previous reviews were hand-searched to identify other relevant studies.

Selection criteria and selection of relevant studies. Study inclusion 'PICO' criteria were as follows: (i) participants: individuals of any age who received a diagnosis of cancer; (ii) intervention/Exposures: assessment of vitamin D status or genetic factors known to affect vitamin $\mathrm{D}$ concentration, metabolism or pathways; (iii) comparators: study reports a quantitative association between cancer outcome and either vitamin D status (e.g., concentration, quartiles, low/high levels) sampled at most 1 year prior to the diagnosis, or any germline genetic variation or gene expression in normal tissue; and (iv) Outcome: cancer-specific or all-cause mortality, or disease progression (e.g., disease-free survival, local recurrence or metastasis). Observational retrospective and prospective cohorts were included.

In relation to patients, exclusion criteria were: (i) pre-cancerous lesions, and (ii) mixed-cancer cohort without site-specific reporting; in relation to exposures: (iii) vitamin D intake and supplementation, (iv) acquired non-germline mutations or tumour gene expression, and (v) predicted vitamin D status; in relation to outcomes: (vi) prognostic markers such as Prostate Specific Antigen or Breslow thickness, (vii) population cancer mortality rates; in relation to study/publication type: (viii) ecological studies, and (ix) reviews, editorials, case reports, conference abstracts and nonclinical publications. If the same patient cohort was reported on more than once, we used the highest quality, largest sample size or most recent publication. Article titles and abstracts were screened for eligibility, independently by two authors (PVS and LZ or FOS). Disagreements were resolved by discussion and review of full text.

Data extraction. The data extraction was performed by a single investigator (PVS or FOS) using the predefined data fields and extraction was cross-checked by a second investigator in its

\section{Box 1. Conversion of continuous HR and $95 \% \mathrm{CI}$} estimate to per $10 \mathrm{ng} \mathrm{ml}^{-1} \mathrm{HR}$ estimates.

To achieve this, we raised the continuous HR (or 'HR per $1 \mathrm{ng} \mathrm{ml}^{-1 \text { ') }}$ ) to the power of 10 to get $[A]$, per $10 \mathrm{ng} \mathrm{ml}^{-1} \mathrm{HR}$ (e.g., continuous HR, 0.89 , hence per $10 \mathrm{ng} \mathrm{ml}^{-1} \mathrm{HR}: 0.89^{\wedge} 10=0.3118$ ). In order to calculate the confidence intervals we first found the $\exp ($ s.e.(beta) $)=[B]$; the standard errors (s.e.) were calculated using the formula below. We then calculated $1.96^{\star}(x-$ $x$ bar $)=[C]$, where $x$ was fixed at $10 \mathrm{ng} \mathrm{ml}^{-1}$ and $x$ bar was the median of all cohort means from the rest of the studies included in the meta-analysis. We found this to be $23 \mathrm{ng} \mathrm{ml}^{-1}$, therefore $1.96^{*}(10-23)=-25.872=[C]$. [B] was then raised to the power of $[C]$, to get $[D]$. Finally, the HR per $10 \mathrm{ng} \mathrm{ml}^{-1}[\mathrm{~A}]$ was multiplied or divided by [D] in order to derive the upper and lower $95 \%$ confidence intervals. Therefore, the resulting HR was $A$ and $95 \% \mathrm{Cl}:\left(A^{\star} D\right)$ to $(A / D)$.

(Continuous HR)^10 $=[\mathrm{A}]=$ per $10 \mathrm{ng} / \mathrm{ml} \mathrm{HR}$

$$
S E=\frac{\log (\text { upper } 95 \% \mathrm{CI})-\log (\mathrm{HR})}{1.96}
$$

$\exp ($ s.e. $($ beta $))=[B]$

$1.96^{*}(x-x b a r)=[C]$

$\mathrm{B}^{\wedge} \mathrm{C}=[\mathrm{D}]$

$A^{\star} D=$ lower $95 \% \mathrm{Cl}$

$\mathrm{A} / \mathrm{D}=$ upper $95 \% \mathrm{Cl}$ 
entirety (FOS or PVS). The data from eligible studies were extracted using a tailored data extraction form that included the following information: first author, publication year, location or ethnicity of patients, sample size, mean age, gender, cancer site (subtype/histology where relevant), cancer stage, any interventions (e.g., chemotherapy), vitamin D exposure studied and important meta-data (time of sampling, mean/median 25OHD values or range for categories being compared; SNP position, name and rs ID, genotypes compared and model: additive, recessive or dominant), covariates considered, details of outcomes studied,

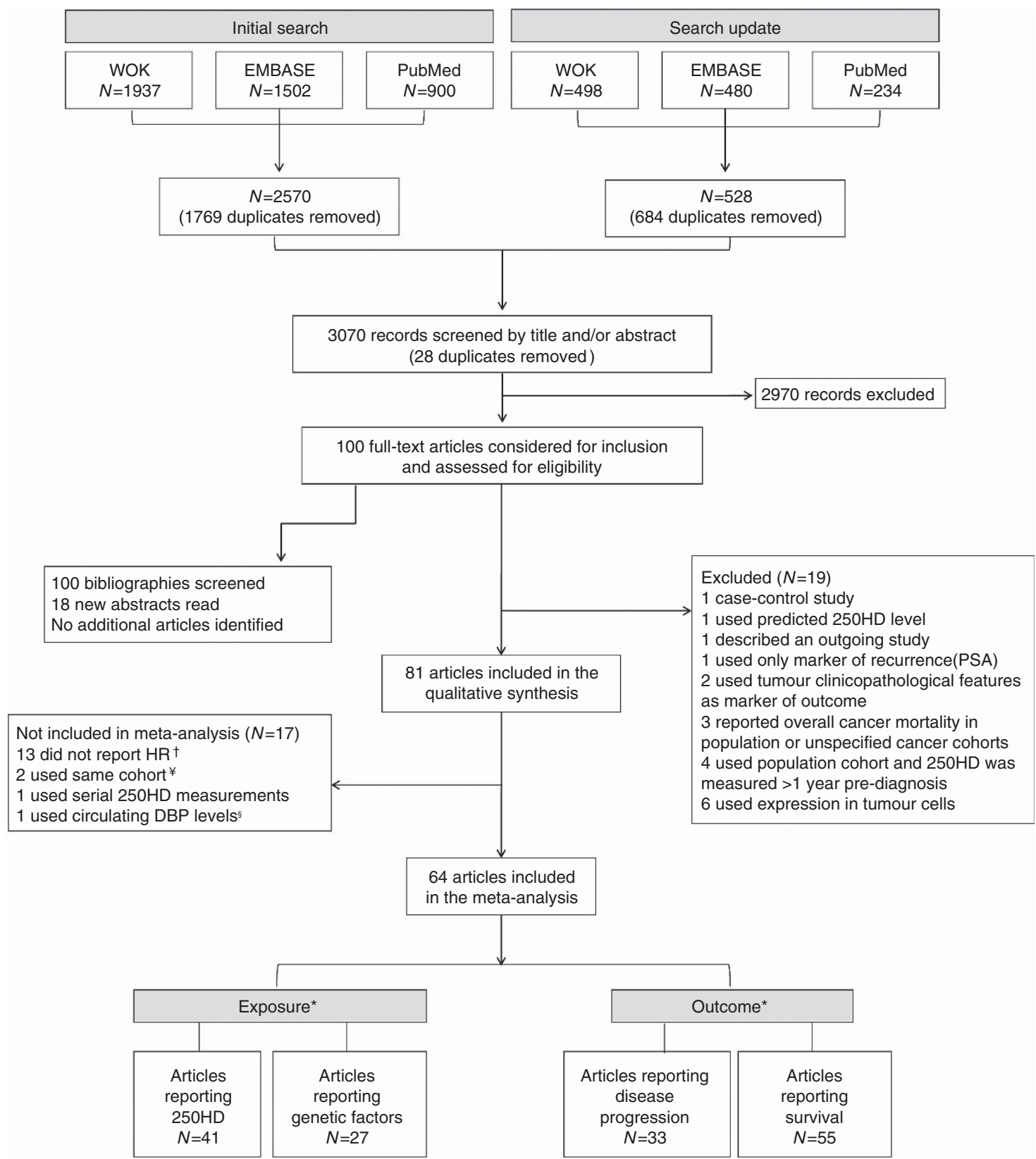

Figure 1. PRISMA Flowchart of the study selection process. Two studies used the same prostate cancer cohort but one reported on circulating $25 \mathrm{OHD}$ and the other on genetic variants, and so both were retained. (Holt et al, 2010, 2013) Three publications used the same initial cohort of lung cancer patients but two reported on different subpopulations of patients (according to disease stage) and so were retained, (Zhou et al, 2007; Heist et al, 2008), while a third reported on different exposures to the first two and so was also retained (Zhou et al, 2006). Finally, four studies reported on the same melanoma patient cohort (Newton-Bishop et al, 2009, 2015; Field et al, 2013; Davies et al, 2014) (one paper scored lower in NOS scoring was excluded (Field et al, 2013), while the remaining three, which reported different exposure or outcomes were retained. ${ }^{\S}$ Only a single study reported impact of circulating vitamin D-binding protein levels on outcome and so could not be included in the meta-analysis. *Includes only exposures and outcomes included in MA. Articles may report on multiple exposure-outcome pairs hence the sum of the pairs is greater than the number of articles included. For example, several papers studied the effect of more than one SNP for example, Zgaga et al, (Zgaga et al, 2014), while many papers studied the impact on both overall survival or progression-free survival for example, Lohman et al (Lohmann et al, 2015). However, where multiple estimates were extracted, no patient was included more than once for a certain exposure or outcome. $\dagger$ Study authors were contacted to provide HR, RR or OR when not reported; 13 did not respond. $¥$ One study (Vrieling et al, 2011) used the same breast cancer cohort as a later, larger study (Vrieling et al, 2014) and as both had the same NOS score, the newer study was included. 25OHD: 25hydroxyvitamin D; DBP: vitamin D binding protein; HR: hazard ratio; PSA: prostate specific antigen; WOK: Web of Knowledge. 
Table 1. Characteristics of studies $(N=64)$ included in the meta-analysis

\begin{tabular}{|c|c|c|c|c|c|c|c|c|c|c|c|}
\hline \multirow[b]{2}{*}{ First author, year } & \multirow[b]{2}{*}{$\begin{array}{l}\text { Cancer } \\
\text { (subtype) }\end{array}$} & \multirow[b]{2}{*}{ HR/OR } & \multirow[b]{2}{*}{$\begin{array}{c}\text { Sample } \\
\text { Size }\end{array}$} & \multirow[b]{2}{*}{ Site } & \multirow[b]{2}{*}{$\begin{array}{c}\text { Follow- } \\
\text { up }(\mathrm{m})\end{array}$} & \multirow[b]{2}{*}{ Events } & \multirow[b]{2}{*}{ NOS } & \multicolumn{2}{|c|}{ Variable } & \multicolumn{2}{|c|}{ Outcome } \\
\hline & & & & & & & & 25OHD & Genetic & $\begin{array}{l}\text { Progr- } \\
\text { ession }\end{array}$ & Survival \\
\hline Anic et al (2012) & Brain (glioma) & $\mathrm{HR}$ & 320 & USA & 28 & 248 cancer deaths & 5 & & 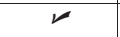 & & $\mathrm{CS}$ \\
\hline Lim et al (2015) & Breast & $\mathrm{HR}$ & 491 & Korea & 86 & $\begin{array}{l}32 \text { recurrences; } 22 \\
\text { cancer deaths }\end{array}$ & 8 & $\boldsymbol{\nu} \mathrm{BT}$ & & DFS & $\mathrm{CS}$ \\
\hline Lohmann et al (2015) & Breast & $\mathrm{HR}$ & 934 & Canada & 112 & Not given & 4 & $\boldsymbol{\nu B T}$ & & RFS & OS \\
\hline Clark et al (2014) & Breast & $\mathrm{HR}$ & 82 & USA & $>36$ & 23 relapses or deaths & 5 & $\boldsymbol{\nu B T}$ & & RFS & \\
\hline Vrieling et al (2014) & Breast & $\mathrm{HR}$ & 2177 & Germany & 64 & $\begin{array}{l}206 \text { cancer deaths, } \\
241 \text { recurrences or } \\
\text { deaths }\end{array}$ & 7 & レ $66 \% \mathrm{BT}$ & & DFS & CS \\
\hline Mishra et al (2013) & Breast & OR & 232 & USA & NA & Not given & 5 & & $\boldsymbol{\nu}$ & DFS & \\
\hline Pande et al (2013) & Breast & $\mathrm{HR}$ & 1029 & USA & 114 & $\begin{array}{l}266 \text { recurrences or } \\
\text { deaths }\end{array}$ & 6 & & 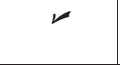 & DFS & \\
\hline Perna et al (2013a) & Breast & $\mathrm{HR}$ & 498 & Germany & 60 & 48 cancer deaths & 7 & & $\nu$ & & $\mathrm{CS}$ \\
\hline Villasenor et al (2013) & Breast & $\mathrm{HR}$ & 585 & USA & 110 & 48 cancer deaths & 7 & $\boldsymbol{V A T}$ & & & CS \\
\hline Hatse et al (2012) & Breast & $\mathrm{HR}$ & 1800 & Belgium & 56 & $\begin{array}{l}118 \text { relapses; } 64 \\
\text { cancer deaths }\end{array}$ & 5 & $\boldsymbol{\nu B T}$ & & DFI & $\mathrm{CS}$ \\
\hline Jacobs et al (2011) & Breast & OR & 512 & USA & 88 & Not given & 5 & $\boldsymbol{V A T}$ & & $\mathrm{R}$ & OS \\
\hline Kim et al (2012) & Breast & $\mathrm{HR}$ & 310 & Korea & 23 & $\begin{array}{l}33 \text { metastases or } \\
\text { deaths }\end{array}$ & 7 & $\boldsymbol{\nu} \mathrm{BT}$ & & DFS & \\
\hline Goodwin et al (2009) & Breast & $\mathrm{HR}$ & 512 & Canada & 139 & $\begin{array}{l}116 \text { recurrences; } 106 \\
\text { deaths }\end{array}$ & 7 & $\boldsymbol{\nu} \mathrm{BT}$ & & $R$ & OS \\
\hline Goode et al (2002) & Breast & $\mathrm{HR}$ & 721 & UK & NA & 200 deaths & 6 & & $\nu$ & & OS \\
\hline Lundin et al (1999) & Breast & RR & 111 & Sweden & 67 & 44 deaths & 4 & & $\nu$ & & OS \\
\hline Tretli et al (2012) & $\begin{array}{l}\text { Breast, colon, lung, and } \\
\text { lymphoma }\end{array}$ & $\mathrm{HR}$ & 658 & Norway & $>60$ & 343 cancer deaths & 7 & $\boldsymbol{\nu} \mathrm{BT}$ & & & CS \\
\hline Wesa et al (2015) & Colorectal & $\mathrm{HR}$ & 250 & USA & NA & 153 deaths & 5 & $\boldsymbol{\nu} \mathrm{BT}$ & & & OS \\
\hline Zgaga et al (2014) & Colorectal & $\mathrm{HR}$ & 1598 & UK & 107 & 363 cancer deaths & 8 & $\boldsymbol{\nu A T}$ & $\boldsymbol{r}$ & & $\mathrm{CS}$ \\
\hline Perna et al (2013b) & Colorectal & $\mathrm{HR}$ & 1397 & Germany & 60 & 336 cancer deaths & 6 & & $\nu$ & & CS \\
\hline Szkandera et al (2013) & Colorectal & $\mathrm{HR}$ & 264 & Austria & 53 & 45 recurrences & 5 & & $\nu$ & $\mathrm{R}$ & \\
\hline Fedirko et al (2012) & Colorectal & $\mathrm{HR}$ & 1202 & Europe & 73 & 444 cancer deaths & 8 & $\boldsymbol{\nu} \mathrm{BD}$ & $\nu$ & & $\mathrm{CS}$ \\
\hline $\mathrm{Ng}$ et al (2011) & Colorectal & $\mathrm{HR}$ & 515 & USA & 61 & $\begin{array}{l}440 \text { progression; } 475 \\
\text { deaths }\end{array}$ & 5 & $\boldsymbol{\nu B T}$ & & TTP & OS \\
\hline Mezawa et al (2010) & Colorectal & $\mathrm{HR}$ & 257 & Japan & 32 & $\begin{array}{l}30 \text { cancer deaths; } \\
\text { recurrences not given }\end{array}$ & 5 & $\boldsymbol{\nu N S}$ & & DFS & CS \\
\hline $\mathrm{Ng}$ et al (2008) & Colorectal & $\mathrm{HR}$ & 304 & USA & 78 & 96 cancer deaths & 7 & $\boldsymbol{\nu} \mathrm{BD}$ & & & $\mathrm{CS}$ \\
\hline Ren et al (2012) & Gastric & $\mathrm{HR}$ & 197 & China & $>60$ & 106 deaths & 5 & $\boldsymbol{\nu} \mathrm{BT}$ & & & OS \\
\hline Lee et al (2014) & Haematological (AML) & $\mathrm{HR}$ & 97 & USA & 16 & $\begin{array}{l}55 \text { relapses; } 51 \\
\text { deaths }\end{array}$ & 4 & $\boldsymbol{\nu B T}$ & & $R$ & OS \\
\hline Shanafelt et al (2011) & Haematological (CLL) & $\mathrm{HR}$ & 543 & USA & 118 & $\begin{array}{l}201 \text { progression; } 96 \\
\text { deaths }\end{array}$ & 8 & $\boldsymbol{\nu N S}$ & & TTT & OS \\
\hline Aref et al (2013) & $\begin{array}{l}\text { Haematological (CLL, } \\
\text { NHL) }\end{array}$ & $\mathrm{HR}$ & 195 & Egypt & 60 & 118 deaths & 5 & $\boldsymbol{\nu} \mathrm{BT}$ & & & OS \\
\hline Drake et al (2010) & $\begin{array}{l}\text { Haematological } \\
(\mathrm{DLBCL})\end{array}$ & $\mathrm{HR}$ & 983 & USA & 35 & $\begin{array}{l}404 \text { events; } 168 \\
\text { cancer deaths }\end{array}$ & 6 & レ $66 \% \mathrm{BT}$ & & EFF & CS \\
\hline Pardanani et al (2011) & $\begin{array}{l}\text { Haematological (PMF, } \\
\text { MDS) }\end{array}$ & $\mathrm{HR}$ & 321 & USA & 34 & $\begin{array}{l}36 \text { progression; } 171 \\
\text { deaths }\end{array}$ & 4 & $\boldsymbol{\nu B T}$ & & LFS & OS \\
\hline Bittenbring et al (2014) & Haemotological (BCL) & $\mathrm{HR}$ & 359 & Germany & 49 & Not given & 4 & $\boldsymbol{\nu A T}$ & & EFF & OS \\
\hline Kelly et al (2015) & Haemotological (FL) & $\mathrm{HR}$ & 423 & USA & 65 & $\begin{array}{l}193 \text { progression; } 58 \\
\text { deaths }\end{array}$ & 5 & $\boldsymbol{\nu \mathrm { BT }}$ & & PFS & OS \\
\hline Azad et al (2013) & Head and neck & $\mathrm{HR}$ & 522 & Canada & $>53$ & 214 deaths & 8 & & $\boldsymbol{\nu}$ & & OS \\
\hline Zeljic et al (2012) & Head and neck & OR & 110 & Serbia & $28-100$ & Not given & 5 & & $\nu$ & & CS \\
\hline Meyer et al (2011) & Head and neck & $\mathrm{HR}$ & 540 & Canada & 96 & $\begin{array}{l}119 \text { recurrences; } 223 \\
\text { deaths }\end{array}$ & 8 & $\boldsymbol{\nu B T}$ & & $R$ & OS \\
\hline Gugatschka et al (2011) & Head and neck (SCC) & $\mathrm{RR}$ & 88 & Austria & NA & $\begin{array}{l}31 \text { progression; } 29 \\
\text { deaths }\end{array}$ & 4 & $\boldsymbol{\nu B T}$ & & DFS & OS \\
\hline Hama et al (2011) & Head and neck (SCC) & $\mathrm{HR}$ & 204 & Japan & 34 & $\begin{array}{l}103 \text { progression or } \\
\text { deaths }\end{array}$ & 6 & & $\nu$ & DFS & \\
\hline Finkelmeier et al (2014) & Liver (HCC) & $\mathrm{HR}$ & 200 & Germany & 11 & 60 deaths & 6 & $\boldsymbol{\nu B T}$ & & & OS \\
\hline Zhou et al (2007) & Lung & $\mathrm{HR}$ & 447 & USA & 72 & 126 cancer deaths & 7 & $\boldsymbol{\nu B T}$ & & & CS \\
\hline Liu et al (2011) & Lung (AC, SCC) & $\mathrm{HR}$ & 568 & China & 19 & 311 deaths & 6 & $\nu \mathrm{NS}$ & $\nu$ & & OS \\
\hline Heist et al (2008) & Lung (AC, SCC) & $\mathrm{HR}$ & 294 & USA & 42 & 233 deaths & 6 & $\boldsymbol{\nu N S}$ & $\boldsymbol{r}$ & & OS \\
\hline
\end{tabular}


Table 1. (Continued)

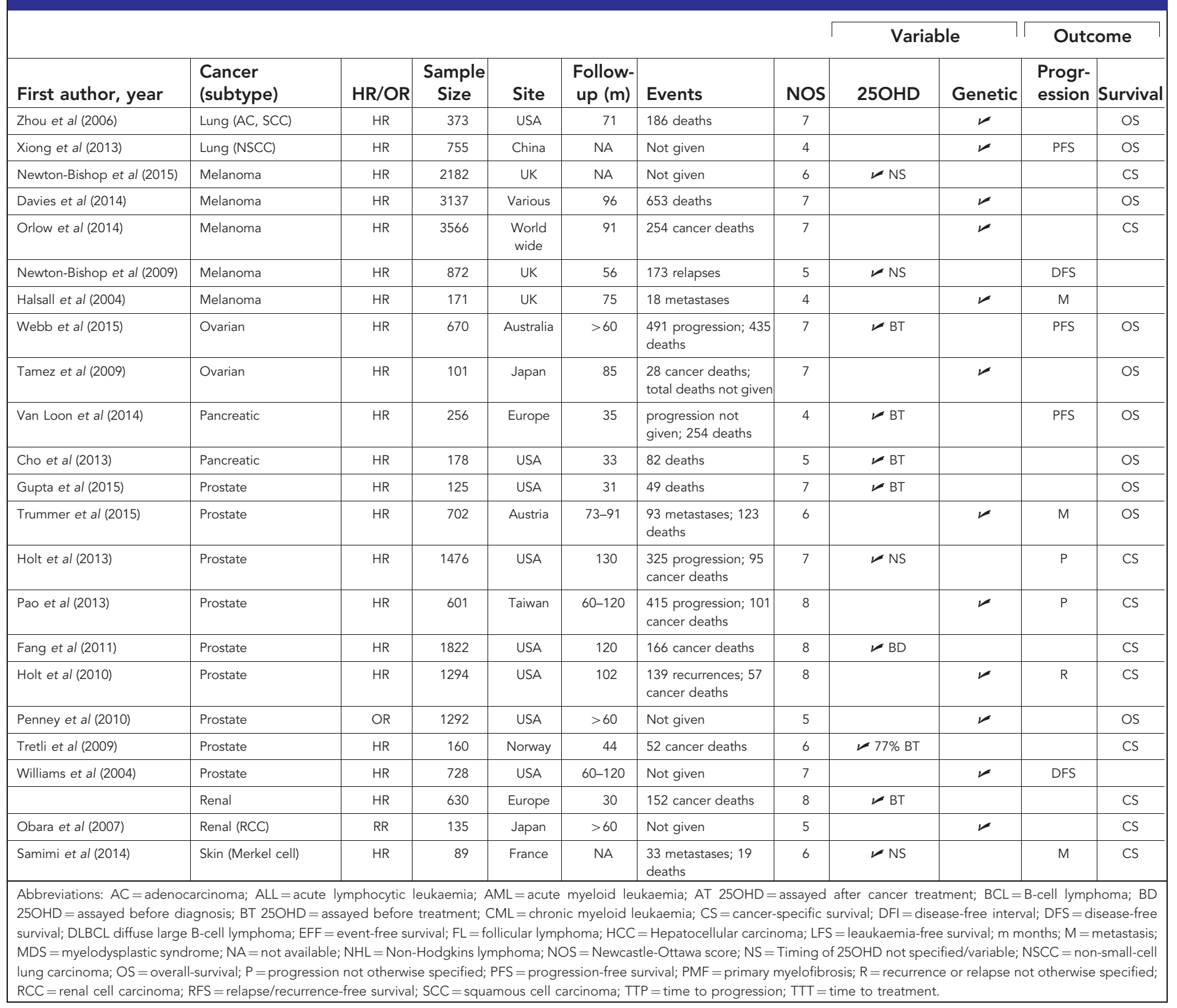

and follow-up time. Finally, hazard ratios (HR) and 95\% confidence intervals (95\% CIs) adjusted for the maximum number of confounding variables were extracted. We preferentially focused on cancer-specific mortality, but if these data were not available, all-cause mortality was used instead. Relative risk estimates (RR) or adjusted odds ratios (OR) were extracted where HR were not given and used in meta-analysis (Symons and Moore, 2002). Study authors were contacted to provide additional information where needed.

Quality assessment. The methodological quality of all studies included in the systematic review was performed using the Newcastle-Ottawa Quality Assessment Scale (NOS; Wells et al, 2000). Two investigators (PVS and FOS) applied predefined NOS criteria to each study to generate summary quality judgement. The risk of bias was considered 'low' for studies with score of 7 or 8; 'unclear' for score of 5 or 6 , and 'high' for score of 4 or lower.

Exposure assessment. The association between circulating 25OHD and outcomes was summarised in meta-analyses by comparing the risk in the highest to the lowest reported category. The majority of studies used vitamin D categories such as quartiles or tertiles. To enable inclusion of studies that used 25OHD as a continuous variable, we sought to transform the 'continuous HR' into a 'HR per $10 \mathrm{ng} \mathrm{ml}^{-1}$, (Box 1).

Genetic factors. For SNPs, the rs number naming convention was typically used in the paper and some recoding was needed to ensure that uniform reference system was followed. For example, where a restriction fragment length polymorphism was referenced, the mutation and risk allele were recoded (e.g., FokI $f$ allele was converted to the rs2228570 $T$ allele). The genome browser ENSEMBL (80 GRCh38.p2) was used to determine if alias names existed (e.g., FokI, rs10735810 and rs2228570 are the same variant). HR values were inverted where needed, so that the same allele acted as the reference. Where additive models were used, the HR values were squared in order to approximate the HR value for comparison between two homozygotes.

Statistical analysis. We conducted meta-analyses for a range of exposure-outcome pairs by cancer site and across all sites. A metaanalysis was performed if at least two studies considered the same exposure-outcome pair. The same study may have been included multiple times in different meta-analyses if it reported on multiple 
subpopulations, outcomes, and/or exposures. The extracted HRs and 95\% CIs were used to calculate the pooled HR estimates. The standard errors (s.e.) were used to calculate weighting for each study. The DerSimonian and Laird random-effects model was used to calculate pooled $\mathrm{HR}$ because of the a priori expected heterogeneity between studies, due to differences among populations and methodological dissimilarities between studies; most notably, different definition of 25OHD categories. All analyses were performed in R (R Core Team, 2013), and the R-package 'metafor' was used for meta-analyses (Viechtbauer and Cheung, 2010). $P$-value $<0.05$ was considered statistically significant.
In order to assess the impact of study quality on results, metaanalyses were rerun (i) after exclusion of studies at high risk of bias, (ii) limited to studies at low risk of bias only, (iii) limited to studies that looked at cancer-specific mortality, (iv) excluding studies that used 25OHD as a continuous variable, and (v) excluding studies that reported RR or OR. The $I^{2}$ statistic was calculated to quantify the degree of heterogeneity between studies and assess impact on the meta-analysis (Higgins et al, 2003). To further explore this issues arising due to the striking differences in 25OHD category definition, we conducted a stratified analysis (Cochrane, 2011) according to: (vi) the difference in mean/median 25OHD between

\section{Table 2. Characteristics of studies $(N=17)$ included in the qualitative synthesis}

\begin{tabular}{|c|c|c|c|c|c|c|c|c|c|c|c|}
\hline \multirow[b]{2}{*}{$\begin{array}{l}\text { First author, } \\
\text { year }\end{array}$} & \multirow[b]{2}{*}{$\begin{array}{c}\text { Cancer } \\
\text { (subtype) }\end{array}$} & \multirow[b]{2}{*}{ Size } & \multirow[b]{2}{*}{$\begin{array}{l}\text { Follow- } \\
\text { up }(\mathrm{m})\end{array}$} & \multirow[b]{2}{*}{ Events } & \multirow[b]{2}{*}{ NOS } & \multicolumn{2}{|c|}{ Variable } & \multicolumn{2}{|c|}{ Outcome } & \multirow[b]{2}{*}{ Author conclusion } & \multirow[b]{2}{*}{$\begin{array}{l}\text { Reason } \\
\text { excluded }\end{array}$} \\
\hline & & & & & & 25OHD & Genetic & Progression & Survival & & \\
\hline $\begin{array}{l}\text { Obermannova et al } \\
\text { (2015) }\end{array}$ & Colorectal & 84 & 24 & Not given & 4 & $\mathscr{V}$ & & PFS & OS & $\begin{array}{l}\text { Consistently low } 25 \mathrm{OHD} \\
\text { (always }<16 \mathrm{ng} / \mathrm{ml} \text { ) associated } \\
\text { with worse PFS and OS }\end{array}$ & $\begin{array}{l}\text { Serial } \\
25 O H D\end{array}$ \\
\hline Turner et al (2013) & Lung (NSCC) & 142 & 52 & Not given & 7 & & & & CS & $\begin{array}{l}\text { Low serum DBP levels } \\
\text { predicted lung cancer-specific } \\
\text { death }(P=0.04)\end{array}$ & $\begin{array}{l}\text { Only } \\
\text { paper } \\
\text { reporting } \\
\text { DBP }\end{array}$ \\
\hline Turna et al (2012) & Lung(NSCC) & 62 & NA & Not given & 5 & & 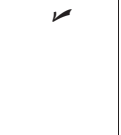 & & OS & $\begin{array}{l}\text { Haplotype analysis revealed } \\
\text { rs731236 (Taql)_rs2228570 } \\
\text { (Fokl) TTFf/TtFf haplotype } \\
\text { associated with reduced OS } \\
(P=0.04)\end{array}$ & $\begin{array}{l}\text { No } \\
\text { individual } \\
\text { SNP HR }\end{array}$ \\
\hline Bade et al (2014) & Melanoma & 324 & NA & Not given & 6 & 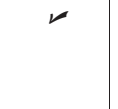 & & & OS & $\begin{array}{l}\text { Increased } 25 \mathrm{OHD}(\mathrm{Q} 4 \vee \mathrm{Q} 1) \\
\text { associated with increased OS } \\
195 \text { months } \vee 80 \text { months } \\
(P=0.049)\end{array}$ & No HR \\
\hline Der et al (2014) & Prostate & 16535 & 60 & 4613 deaths & 5 & $\nu$ & & & OS & $\begin{array}{l}\text { Vitamin } D \text { deficiency } \\
\text { significantly associated with } \\
\text { reduced survival }(<0.001)\end{array}$ & No HR \\
\hline Dickinson et al (2010) & $\begin{array}{l}\text { Haematological } \\
\text { (CML) }\end{array}$ & 228 & NA & $\begin{array}{c}55 \text { relapses; } \\
84 \text { deaths }\end{array}$ & 5 & & $\nu$ & $\mathrm{R}$ & OS & $\begin{array}{l}\text { No data provided on impact of } \\
\text { VDR variants }\end{array}$ & No HR \\
\hline Furuya et al (1999) & Prostate & 66 & NA & Not given & 3 & & $レ$ & PFS & & $\begin{array}{l}\text { Taql TT genotype associated } \\
\text { with shorter PFS }(P=0.07)\end{array}$ & No HR \\
\hline Hansson et al (2014) & $\begin{array}{l}\text { Haematological } \\
\text { (AML, ALL, CML, } \\
\text { MDS) }\end{array}$ & 123 & 96 & $\begin{array}{c}29 \text { relapses; } \\
31 \text { deaths }\end{array}$ & 6 & $\nu$ & & $\mathrm{R}$ & OS & $\begin{array}{l}25 \mathrm{OHD}<20 \mathrm{ng} / \mathrm{ml} \text { associated } \\
\text { with reduced } \mathrm{OS}(P=0.01) \text { and } \\
\text { increased relapse }(P=0.03)\end{array}$ & No HR \\
\hline Kim et al (2012) & Haematological & 100 & 105 & $\begin{array}{l}12 \text { relapses; } \\
4 \text { deaths }\end{array}$ & 4 & & $レ$ & EFS & OS & $\begin{array}{l}\text { VDR rs2228570 Fokl genotype } \\
\text { did not impact survival in } \\
\text { paediatric ALL }\end{array}$ & No HR \\
\hline Nurnberg et al (2009) & Melanoma & 205 & NA & \begin{tabular}{c|}
118 \\
metastases
\end{tabular} & 4 & 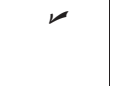 & & $\mathrm{M}$ & & $\begin{array}{l}25 \mathrm{OHD}>20 \mathrm{ng} / \mathrm{l} \text { associated } \\
\text { with increased time to distant } \\
\text { metastatic disease }(P=0.64)\end{array}$ & No HR \\
\hline Peiris et al (2013) & Bladder & 4126 & NA & 2025 deaths & 6 & $\nu$ & & & OS & $\begin{array}{l}25 \mathrm{OHD}<20 \mathrm{ng} / \mathrm{ml} \text { associated } \\
\text { with reduced } \mathrm{OS}(\mathrm{X} 2=10.44 \\
P=0.001)\end{array}$ & No HR \\
\hline Silvagno et al (2010) & $\begin{array}{l}\text { Ovarian } \\
\text { (Epithelial) }\end{array}$ & 26 & NA & Not given & 2 & & $\nu$ & & OS & $\begin{array}{l}\text { Increased platelet VDR } \\
\text { expression ( }>50 \mathrm{fMol}) \\
\text { associated with increased OS } \\
(P=0.12)\end{array}$ & No HR \\
\hline $\begin{array}{l}\text { Walentowicz- } \\
\text { Sadlecka et al (2012) }\end{array}$ & Ovarian & 72 & 60 & 45 deaths & 6 & $\nu$ & & & OS & $\begin{array}{l}25 \mathrm{OHD}<10 \mathrm{ng} / \mathrm{ml} \text { associated } \\
\text { with reduced OS }(P<0.04)\end{array}$ & No HR \\
\hline $\begin{array}{l}\text { Yagmurdur et al } \\
(2009)\end{array}$ & Breast & 56 & 60 & \begin{tabular}{c|}
5 \\
recurrences
\end{tabular} & 3 & & $\nu$ & $R$ & & $\begin{array}{l}\text { rs1544410 (Bsml) genotype not } \\
\text { associated with local recurrence } \\
\text { or metastasis } P>0.05\end{array}$ & No HR \\
\hline Yiallourou et al (2014) & Breast & 87 & 60 & Not given & 3 & & $\boldsymbol{\nu}$ & PFS & OS & $\begin{array}{l}\text { rs } 2228570 \text { Fokl ff associated } \\
\text { with reduced PFS } 35 \text { months vs } \\
>54 \text { months }(P=0.08)\end{array}$ & No HR \\
\hline Field et al (2013) & Melanoma & 795 & 56 & $\begin{array}{c}137 \text { cancer } \\
\text { deaths }\end{array}$ & 4 & 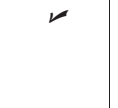 & & & $\mathrm{CS}$ & $\begin{array}{l}8 \mathrm{ng} / \mathrm{ml} \text { incremental increase in } \\
25 \mathrm{OHD} \text { associated with } \\
\text { improved DFS }(P=0.02) \text { and } \\
\text { MSS }(P=0.05)\end{array}$ & $\begin{array}{l}\text { Duplicate } \\
\text { patient } \\
\text { cohort }\end{array}$ \\
\hline Vrieling et al (2011) & Breast & 1295 & 70 & $\begin{array}{c}182 \\
\text { recurrence } \\
\text { or } \\
\text { metastases; } \\
183 \text { deaths } \\
\end{array}$ & 7 & $\nu$ & & DFS & OS & $\begin{array}{l}\text { Low } 25 \mathrm{OHD} \text { significantly } \\
\text { associated with worse DFS and } \\
\text { OS }\end{array}$ & $\begin{array}{l}\text { Duplicate } \\
\text { patient } \\
\text { cohort }\end{array}$ \\
\hline $\begin{array}{l}\text { Abbreviations: } \mathrm{AML}= \\
\mathrm{D} \text { binding protein; } \mathrm{EF} \\
\text { Newcastle-Ottawa scc } \\
\text { nucleotide polymorph }\end{array}$ & $\begin{array}{l}\text { ute myeloid leu } \\
=\text { event-free sur } \\
\text {; } N S C C=\text { non }\end{array}$ & imo & $\begin{array}{l}\text { acute ly } \\
\text { mtomo }\end{array}$ & locytic leuk & ia; & $=$ Cnro & 100 & $\begin{array}{l}\mathrm{a} ; \mathrm{CS}= \\
=\text { myel }\end{array}$ & syndr & $\begin{array}{l}\text { al; DFS = disease-free survival; DB } \\
\text {; MSS = melanoma specific survi } \\
\text { apse not otherwise specified; S }\end{array}$ & $\begin{array}{l}\mathrm{BP}=\text { vitamin } \\
\text { ival; } \mathrm{NOS}= \\
\mathrm{SNP}=\text { single }\end{array}$ \\
\hline
\end{tabular}


'high' and 'low' categories compared (below or $\geqslant 20 \mathrm{ng} \mathrm{ml}^{-1}$ ), and (vii) the degree of deficiency in 'low' category (mean/median $25 \mathrm{OHD}$ concentration below or $\geqslant 12.5 \mathrm{ng} \mathrm{ml}^{-1}$ ). Publication and selection bias was investigated by checking for asymmetry in the funnel plots and running the Egger's regression test (Sterne and Egger, 2001).

\section{RESULTS}

A flowchart illustrating study selection is shown in Figure 1. After removal of duplicates, the search yielded 3070 potential articles. Irrelevant articles were eliminated after screening titles $(N=2708)$

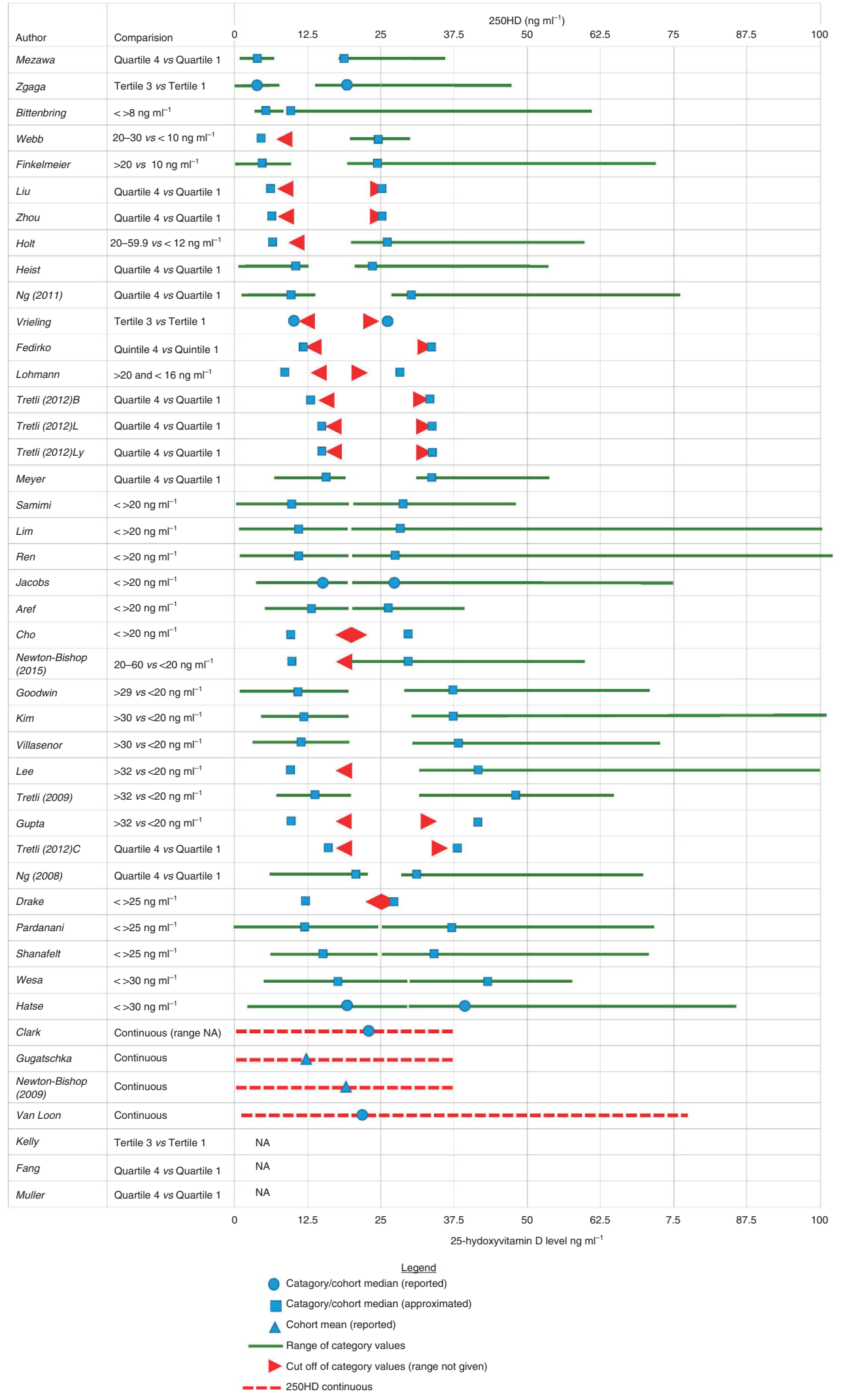


or abstracts $(N=262)$. One hundred full-texts were considered for inclusion and assessed for eligibility and 19 were excluded. Finally, 81 articles were kept for the systematic review and 64 of these were included in the meta-analysis. The main characteristics of included studies are summarised in Table 1 and Table 2.

Assessment of included studies. The risk of bias assessment revealed that 35 studies (43\%) had a low risk of bias, 35 (43\%) had an uncertain, and 11 (14\%) had a high risk of bias. The risk of bias assessment summary per each domain is shown in Supplementary Figure S1 and individual study scores in Supplementary Figure S2. Sixty-four studies were included in the meta-analysis, with a total of 44165 patients. Most studies were conducted in the USA $(N=24)$ and Europe; breast cancer was most commonly studied $(N=15)$, followed by nine studies (each) on prostate cancer and colorectal cancer. In total, $157 \mathrm{HR}$ estimates for a range of exposure-outcome pairs were included in meta-analyses: 77 estimates (from 41 studies) for association with 25OHD, and 80 estimates (from 27 studies) relating to genetic factors. Separate estimates were extracted for different patient subgroups (e.g., different type of haematological malignancy (Drake et al, 2010)), different exposures (e.g., multiple polymorphisms (Zgaga et al, 2014)), or different outcome (i.e., survival or disease progression (Lohmann et al, 2015)). No patients were included more than once in meta-analysis, as separate meta-analyses have been conducted for each exposure-outcome pair. Very large differences were observed in definition of vitamin D categories being compared. For example, the median $25 \mathrm{OHD}$ concentration was $18.26 \mathrm{ng} \mathrm{ml}^{-1}$ in the 'high' category in one study, (Zgaga et al, 2014) yet this was actually lower than the median $\left(19.7 \mathrm{ng} \mathrm{ml}^{-1}\right)$ in the 'low' category in another study (Hatse et al, 2012). The variety of vitamin D categories, cutoffs and means/medians used are presented in Figure 2 and Supplementary Figure S3.

\section{Meta-analysis of 250HD studies}

Circulating vitamin $D$ and survival. Forty-eight estimates from 38 studies were included in the meta-analysis of 25OHD and survival (17 studies (45\%) examined cancer-specific mortality), comprising in total 24013 cancer patients. Twelve cancer types were represented: breast, haematological, head and neck, colorectal, lung, prostate, skin, pancreatic liver, gastric, kidney and ovarian cancers. Overall, a significantly reduced risk of death was observed when comparing those with high to those with low vitamin D levels; meta-analysis $\mathrm{HR}=0.74,95 \% \mathrm{CI}=0.66$ to 0.82 (Figure 3). The same significant trend was also observed in subgroup metaanalysis for breast $(\mathrm{HR}=0.75,95 \% \mathrm{CI}=0.56-0.95)$, haematological $(\mathrm{HR}=0.59,95 \% \mathrm{CI}=0.42-0.77)$ and colorectal cancers $(\mathrm{HR}=0.75,95 \% \mathrm{CI}=0.60-0.90)$. There was also a non-significant trend towards better survival with increased 25OHD observed in the subgroup analysis for prostate, skin, head and neck cancers. Virtually no change in direction or significance in overall effect was observed in sensitivity analyses when excluding studies at high risk of bias ( $\mathrm{HR}=0.73,95 \% \mathrm{CI}=0.65-0.80)$, focusing on the studies at low risk of bias only $(\mathrm{HR}=0.72,95 \% \mathrm{CI}=0.63-0.81)$, excluding studies that used continuous $25 \mathrm{OHD}(\mathrm{HR}=0.73,95 \% \mathrm{CI}=0.65-$ 0.80 ), limited to cancer-specific mortality studies only $(\mathrm{HR}=0.75$, $95 \% \mathrm{CI}=0.65-0.84)$, or to studies that strictly reported $\mathrm{HR}$ $(\mathrm{HR}=0.74,95 \% \mathrm{CI}=0.66-0.82)$. The same was true after selection of studies where the difference in mean/median between high and low categories being compared was over or below $20 \mathrm{ng} \mathrm{ml}^{-1}$; $(\mathrm{HR}=0.70,95 \% \mathrm{CI}=0.60-0.81$, and $\mathrm{HR}=0.71,95 \% \mathrm{CI}=0.55-$ 0.87 , respectively), or when stratifying by the lower category mean/ median below or greater than $12.5 \mathrm{ng} \mathrm{ml}^{-1}(\mathrm{HR}=0.76,95 \%$ $\mathrm{CI}=0.64-0.88$, and $\mathrm{HR}=0.61,95 \% \mathrm{CI}=0.47-0.75$, respectively) (for sensitivity analysis please see supplementary material).

The relationship between circulating vitamin $D$ level and disease progression. Twenty-three studies investigated the association between circulating $25 \mathrm{OHD}$ and disease progression; from these studies 29 estimates were included in our meta-analysis comprising in total 14307 patients with breast, haematological, head and neck, colorectal, prostate, skin, pancreatic, or ovarian cancer. Higher circulating vitamin $\mathrm{D}$ was associated with a significant reduction in disease progression for all cancers combined $(\mathrm{HR}=0.84,95 \%$ $\mathrm{CI}=0.77-0.91$; Figure 4 ); this was also observed in subgroup metaanalysis of breast $(\mathrm{HR}=0.66,95 \% \mathrm{CI}=0.45-0.88)$, haematological $(\mathrm{HR}=0.75,95 \% \mathrm{CI}=0.61-0.88)$ and skin cancer $(\mathrm{HR}=0.77,95 \%$ $\mathrm{CI}=0.58-0.97)$. Findings remain fundamentally unchanged after exclusion of studies at high risk of bias $(\mathrm{HR}=0.82,95 \% \mathrm{CI}=0.74-$ $0.90)$, limited to studies at low risk of bias only ( $\mathrm{HR}=0.80,95 \%$ $\mathrm{CI}=0.70-0.90)$ or excluding studies that used continuous $25 \mathrm{OHD}$ $(\mathrm{HR}=0.81,95 \% \mathrm{CI}=0.73-0.90)$, or limited to studies that strictly reported $\mathrm{HR}(\mathrm{HR}=0.84,95 \% \mathrm{CI}=0.77-0.91)$. The same was true after selection of studies where the difference in mean/median between high and low categories being compared was over or below $20 \mathrm{ng} \mathrm{ml}^{-1} ; \quad(\mathrm{HR}=0.81, \quad 95 \% \quad \mathrm{CI}=0.72-0.90, \quad$ and $\mathrm{HR}=0.75,95 \% \mathrm{CI}=0.55-0.95$, respectively), or when stratifying by the lower category mean/median below or greater than $12.5 \mathrm{ng} \mathrm{ml}^{-1}(\mathrm{HR}=0.84,95 \% \mathrm{CI}=0.71-0.97$, and $\mathrm{HR}=0.77$, $95 \% \mathrm{CI}=0.62-0.92$, respectively) (for sensitivity analysis please see supplementary material).

\section{Vitamin-D-related genetic variation}

VDR and other vitamin D pathway SNPs and survival. Twentyone studies investigated the association between vitamin-D-related genetic variation and survival; $10(48 \%)$ examined cancer-specific

Figure 2. Large variation in definition of vitamin D categories in studies included in systematic review. Where not given in the paper, median $25 \mathrm{OHD}$ concentration for categories compared was requested from study authors and if not subsequently available was approximated. Approximation of the median for each category was performed using the cohort and/or category range where available. For categories defined by numerical cutoffs of $25 \mathrm{OHD}$, the median for the lower category was approximated as the lowest reported $25 \mathrm{OHD}$ value (or 0 if category range not given) added to the midpoint of the category upper cutoff minus the lowest reported 25OHD value. For example, Bittenbring et al (Bittenbring et al, 2014) reported outcome according to $25 \mathrm{OHD}<>8 \mathrm{ng} \mathrm{ml}^{-1}$ groups and reported a study cohort range of 4-61.9. The median of the lower category $\left(<8 \mathrm{ng} \mathrm{ml}^{-1}\right)$ was approximated as the lowest value in the range plus the midpoint of the category that is, $4+((8-4) / 2)=6$. The upper category median was approximated as the category cutoff (that is, the lowest value in that category) added to the midpoint of the lower category. for example, in the Bittenbring et al, paper the median of the upper category was approximated as $8+((8-4) / 2)=10$. Where the compared categories were tertiles, quartiles or quintiles, the median of the lower category and upper categories was the midpoint of the difference between upper cutoff of the lower category compared and the lower cut-off of the higher category compared divided by the number of groups between two categories compared, either subtracted from the upper cutoff of the lower category or added to the lower cutoff of the higher category, respectively. For example, Bade et al, (Bade et al, 2014) grouped patients by quartile of 25OHD and report a cohort range of 4-59.6 ng ml ${ }^{-1}$. Q1 is given as $25 \mathrm{OHD}<9.86 \mathrm{ng} \mathrm{ml}^{-1}$ and Q4 $>24.4 \mathrm{ng} \mathrm{ml}^{-1}$. Therefore, the medians of Q1 and Q4 were approximated as follows: $\mathrm{Q} 1($ median $)=9.86-(((24.4-9.86) / 2) / 2)=6.225$ and $\mathrm{Q} 4($ median $)=24.4+(((24.4-9.86) / 2) / 2)=28$. Insufficient data were reported in three studies to allow graphical illustration of categories or approximation of median. NA=data not reported; For Tretli et al, study: $\mathrm{B}=\mathrm{breast}$; $\mathrm{C}=$ colon; $\mathrm{L}=$ lung; $\mathrm{Ly}=$ lymphoma. 


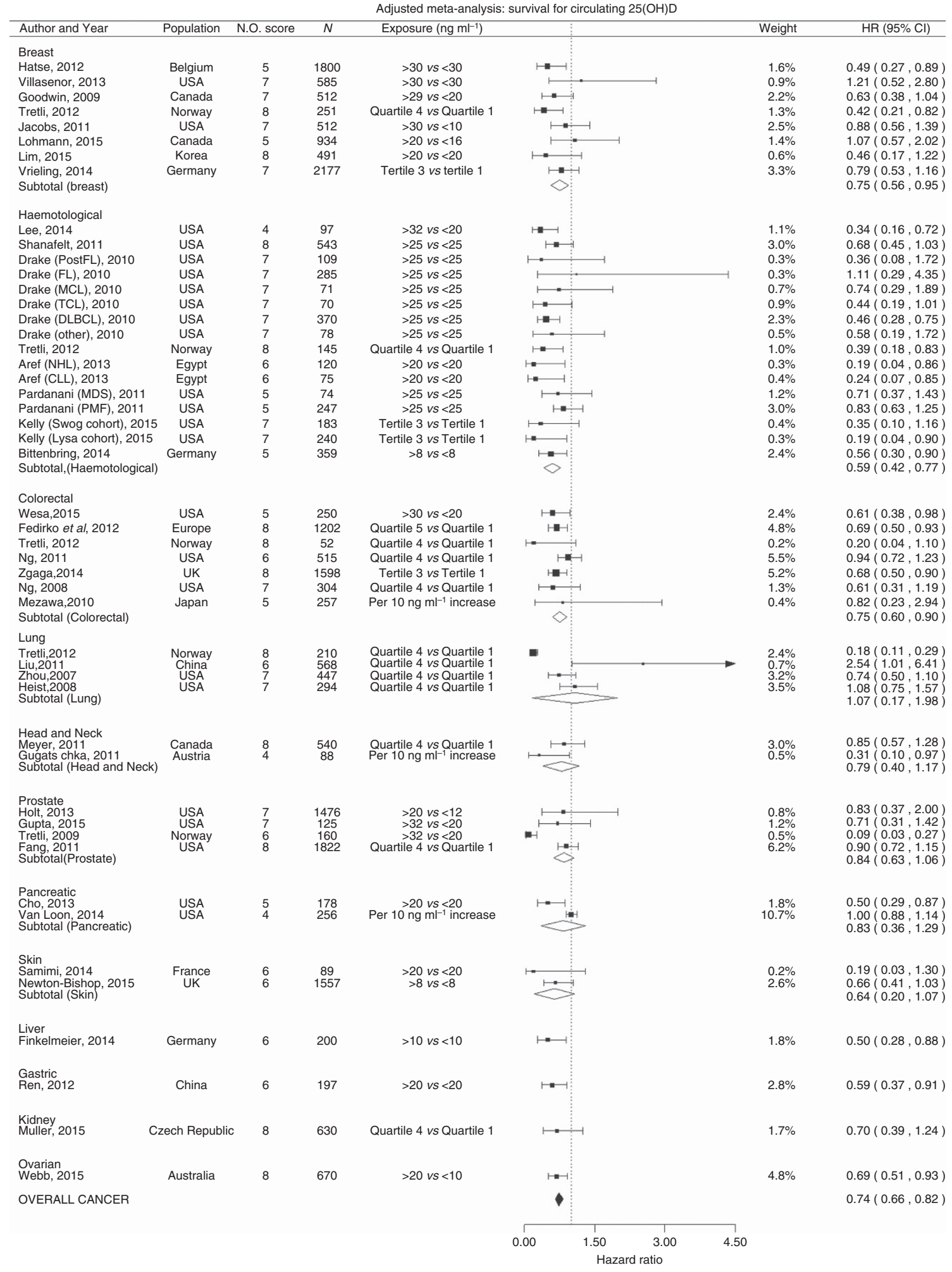

Figure 3. Cancer survival and 25-hydroxyvitamin D concentration: meta-analysis of adjusted hazard ratios. HR are sorted by cancer site and the difference in median between 'high' and 'low' vitamin D categories compared. Acute myeloid leukaemia (AML), Chronic Lymphoid Leukaemia $(\mathrm{CLL})$, and subtypes of non- Hodgkin's lymphoma (NHL) (large B-cell lymphoma (DLBCL), T-cell lymphoma (TCL), Follicular Lymphoma (FL) and mantle cell lymphoma (MCL)) Myelodysplastic syndrome (MDS) and primary myelofibrosis (PMF). $1^{2}=$ breast: 0 , haematological: 0 , colorectal: 0.91 , prostate: 0.68 , head and neck: 0, pancreatic: 0.66 , lung: 0.93 , skin: 0 , overall cancer: 0.18 . Approximated Median in studies using quartiles/tertiles $\left(\mathrm{ng} \mathrm{ml}^{-1}\right)$ : Tretli breast (lower: 12.9, upper: 33.9), Tretli Haematological: (lower:14.3, upper: 34.1), Tretli colorectal: (lower:16.4, upper: 38), Tretli lung: (lower:14.3, upper: 34.1), Vrieling: (lower: 10.6, upper: NA), Kelly (NA), Fedirko: (lower:11.8, upper: 33.4), Ng et al (2011): (lower:9.6, upper: 30.7), Zgaga: (lower:4.4, upper: 18.3), Ng et al (2008): (lower:21, upper: 30.6), Liu: (lower:7, upper: 25.4), Zhou: (lower:7.4, upper: 24.5), Heist: (lower:10.4, upper: 23.9), Meyer: (lower:16.2, upper: 34.2), Fang: (NA), Muller: (NA). 
Adjusted Meta-analysis: Disease progression for circulating 25(OH)D

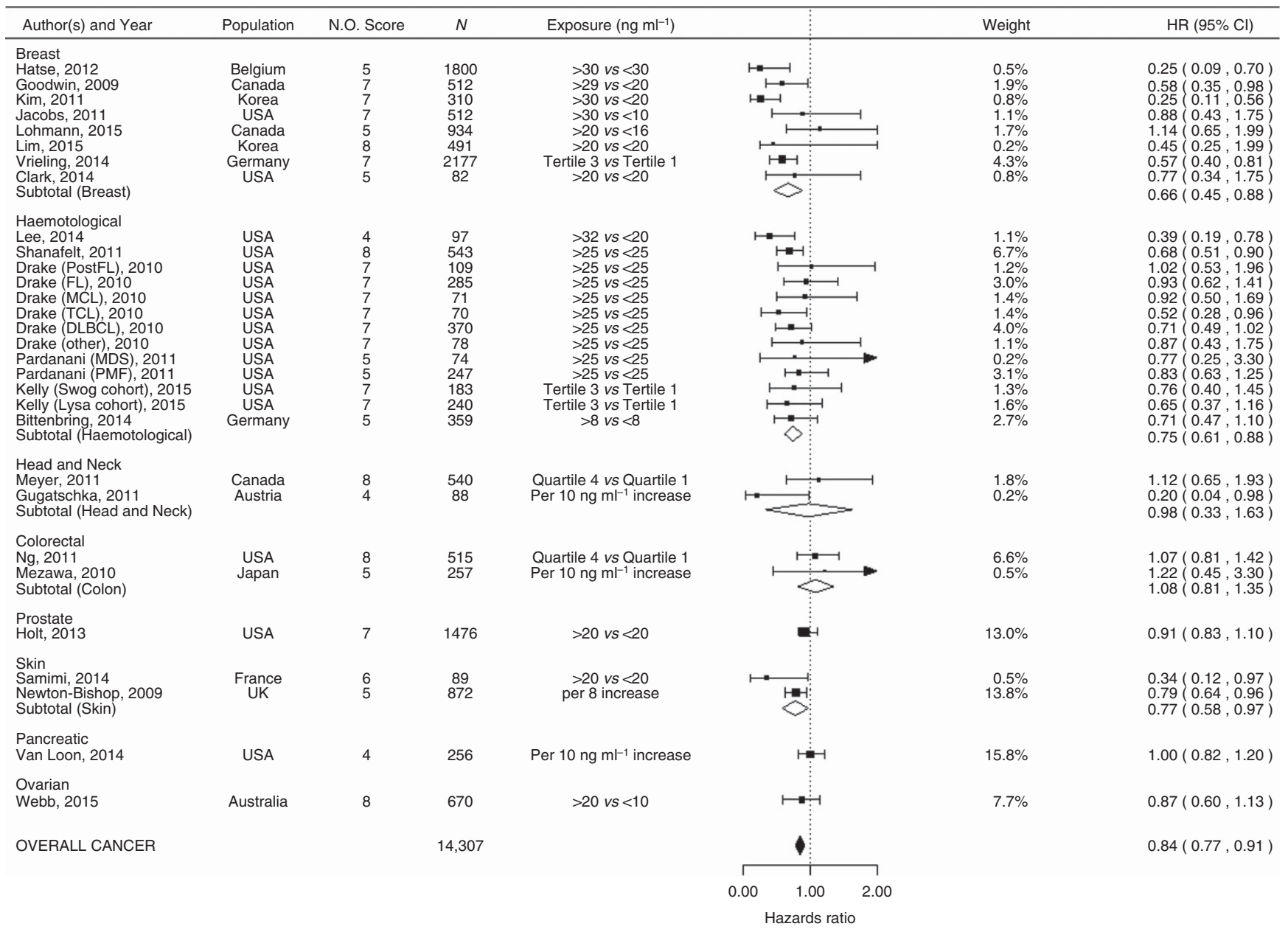

Figure 4. Cancer progression and 25-hydroxyvitamin D concentration: meta-analysis of adjusted hazard ratios. HR are sortd by the difference in median between high and low vitamin D levels compared. Acute myeloid leukaemia (AML), Chronic Lymphoid Leukaemia (CLL), and subtypes of non- Hodgkin's lymphoma (NHL) (large B-cell lymphoma (DLBCL), T-cell lymphoma (TCL), follicular lymphoma (FL) and mantle cell lymphoma $(\mathrm{MCL})) .12$ = breast: 0 , haematological: 0 , colorectal: 0 , head and neck: 0 , skin: 0 overall cancer: 0 . Approximated median in studies using quartiles/ tertiles $\left(\mathrm{ng} \mathrm{ml}^{-1}\right.$ ): Vrieling: (lower: 10.6, upper: NA), Kelly (NA), Meyer: (lower:16.2, upper: 34.2), Ng et al, (2011): (lower:9.6, upper: 30.7).

mortality. By far, the most commonly studied were polymorphisms in VDR gene, particularly rs2228570 (FokI), rs1544410 (BsmI), rs731236 (TaqI), rs11568820 (Cdx2), and rs7975232 (ApaI). In meta-analysis, rs1544410 TT/TC genotypes were associated with worse survival compared to CC genotype ( $\mathrm{HR}=1.40,95 \%$ $\mathrm{CI}=1.05-1.75$; Figure 5 ). The same direction of the effect was observed in the sensitivity analyses after exclusion of studies with NOS $<7$ (Supplementary Figure S4) and those reporting on cancer-specific mortality, but the association was no longer significant (Supplementary Figure S5). In lung cancer patients, a poorer outcome was observed to be associated with rs2228570 TT/ TC carriers $(\mathrm{HR}=1.29,95 \% \mathrm{CI}=1.00-1.57)$ and a consistent albeit non-significant association was found across all cancers ( $\mathrm{HR}=1.26,95 \% \mathrm{CI}=0.96-1.56)$. A significant association was observed with rs731236 (Taq1) variant when limited to studies at low risk of bias (NOS score $\geqslant 7 ; \mathrm{HR}=0.79,95 \% \mathrm{CI}=0.62-0.95$, Supplementary Figure S4). Other genetic factors were investigated in at most three original studies and no other statistically significant results were observed.

VDR and vitamin D pathway SNPs and disease progression. Ten studies examined the effect of genetic variation on disease progression (Figure 6; for sensitivity analysis see Supplementary
Figure S6). In meta-analysis of three studies with a total of 1588 patients, it was observed that $r s 7975232 A A$ carriers had significantly worse survival than CC carriers $(\mathrm{HR}=1.29,95 \%$ $\mathrm{CI}=1.02-1.56)$. Additionally, a suggestive association was observed for vitamin D binding protein variant rs2282679 $(\mathrm{HR}=1.22,95 \% \mathrm{CI}=0.99-1.46)$ in meta-analysis of two studies.

Testing for publication bias and study heterogeneity. There was some evidence of heterogeneity between studies in meta-analysis of 25OHD and some evidence of publication bias (Supplementary Figures S7 and S8). A non-insignificant degree of heterogeneity and evidence of publication bias were observed in some subgroup analysis. Heterogeneity was observed for subgroup analysis of rs1544410, rs7975232, rs2228570 and rs731236, as well as for some individual cancer types while publication bias was observed for rs1544410, rs2228570 and rs731236 (Supplementary Figures S7 and S8).

Studies not included in meta-analysis. Seventeen papers were excluded from the meta-analysis, but their findings were nonetheless considered (Table 2). Eight studies report improved overall and/or progression-free survival among those with higher 25OHD concentration (Vrieling et al, 2011; Walentowicz-Sadlecka et al, 2012; Peiris et al, 2013; Field et al, 2013; Bade et al, 2014; Der et al, 
2014; Hansson et al, 2014; Obermannova et al, 2015) and one study found no association between 25OHD and incidence of metastases (Nurnberg et al, 2009). Seven studies investigated genetic variants and outcome (median sample size: 66). One study reported that the rs731236/rs2228570 (TaqI-FokI, TTFf/TtFf) haplotype was significantly associated with reduced overall survival $(\mathrm{HR}=1.81,95 \% \mathrm{CI}=1.23-3.48, P=0.04)$ (Turna et al, 2012): suggestive associations were reported between progression-free survival and rs731236 (AA) genotype in prostate cancer (Furuya et al, 1999) and rs2228570 TT genotype in breast cancer (Yiallourou et al, 2014), while there was no association found between rs2228570 and paediatric ALL (Kim et al, 2012). No association was observed between rs 1544410 and breast cancer outcome (Yagmurdur et al, 2009). There was a suggestive association between platelet VDR expression and survival in ovarian cancer (Silvagno et al, 2010). Finally, low vitamin D binding protein (DBP) levels were found to be predictive of lung cancer death (Turner et al, 2013).

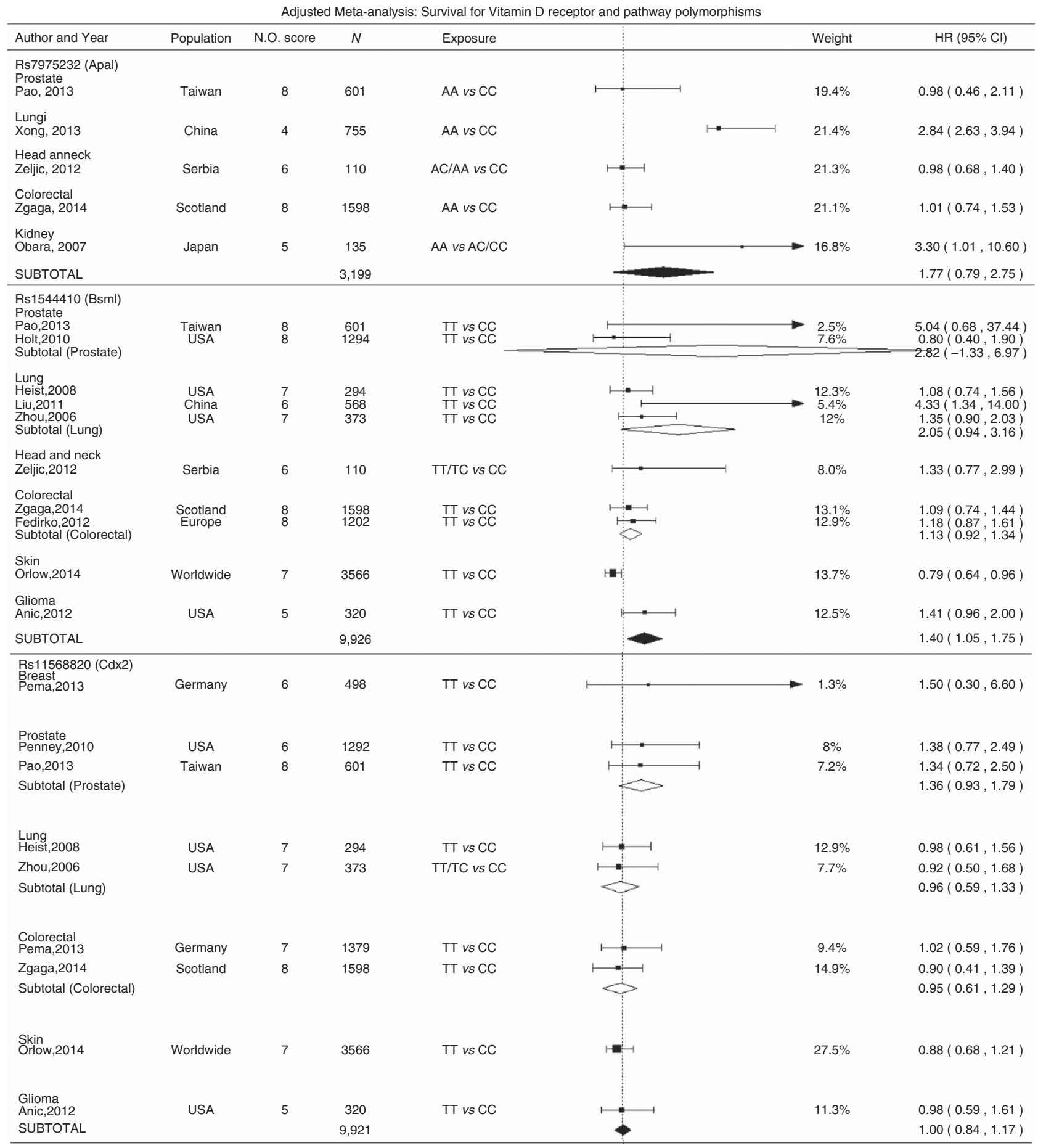

Figure 5. Cancer survival and vitamin D receptor polymorphisms and other vitamin D-related genetic factors: adjusted meta-analysis. $I^{2}$ for Apal: 0.95, Bsml prostate: 0.93, Bsml Lung: 0.93, Bsml colorectal: 0, Bsml All: 0.85, Cdx2 prostate: 0, Cdx2 lung: 0, Cdx2 colorectal: 0, Cdx2 All: 0, Fokl Prostate: 0, Fokl lung: 0, Fokl colorectal: 0, Fokl All: 0.83, Taql breast: 0.88, Taql skin: 0.46, Taql all: 0.86, Cyp24a1(1) all: 0.75, Cyp24a1(2) all: 0.67, GC all: 0, Rs2107301 all: 0, Rs4516035: 0, Rs2238135: 0. 


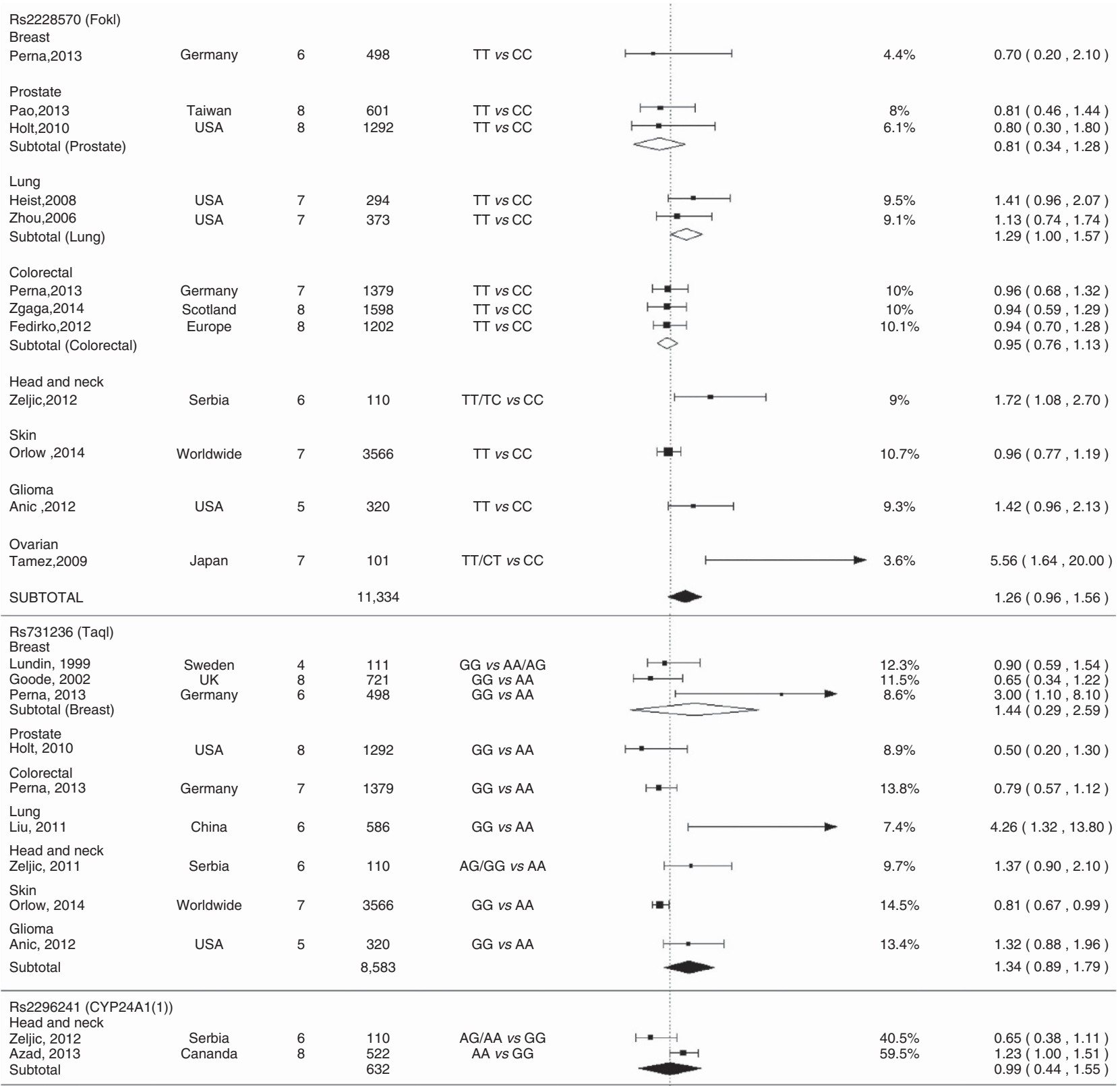

Figure 5. (Continued)

\section{DISCUSSION}

This is the first systematic review with meta-analysis that examines the relationship between cancer outcomes and variation in vitamin $\mathrm{D}$ pathway genes, and also by far the largest review on vitamin $\mathrm{D}$ status and cancer outcome. Our review suggests that higher circulating vitamin $\mathrm{D}$ in cancer patients is associated with a $26 \%$ lower rate of death and a $16 \%$ lower rate of disease progression. The clear association with survival was also observed in site-specific analyses of breast, haematological and colorectal cancers, while an association with reduction in disease progression was also found in those diagnosed with breast, haematological and skin cancer.

Establishing a causal relationship between vitamin D status and cancer progression is challenging because risk factors associated with cancer outcome are often also associated with vitamin D deficiency. For example, the association between 25OHD and improved survival observed in the original studies might be due to $25 \mathrm{OHD}$ being a marker of healthier lifestyle (i.e., healthier diet containing more fish; physical activity and spending time outdoors). However, evidence that genetic factors linked to vitamin $\mathrm{D}$ metabolism and pathways impact upon cancer survival may be used to counter such concerns and support a causal link. In our meta-analysis, we found evidence of an association between the $V D R$ gene variants with functionally characterised effects and cancer outcome. Forty percent higher rate of death was observed in TT carriers at rs 1544410 locus and 26\% higher rate in TT carriers at rs2228570, while $29 \%$ increased risk of disease progression was observed in $A A$ carriers at $r s 7975232$ and $22 \%$ in GG carriers at GC locus.

Evidence from biological studies support a role for these polymorphisms in modulating vitamin D biology. For example, rs2228570 has been shown to affect the translational start site of $1,25(\mathrm{OH})_{2} \mathrm{D}$ and hence its downstream effects (Uitterlinden et al, 2004), while rs1544410 and $r s 7975232$ have been associated with changes in VDR messenger RNA expression (Staal et al, 1996; Uitterlinden et al, 2004). We hypothesise that interactions between mutations in the vitamin $\mathrm{D}$ pathway and vitamin $\mathrm{D}$ status exist, 


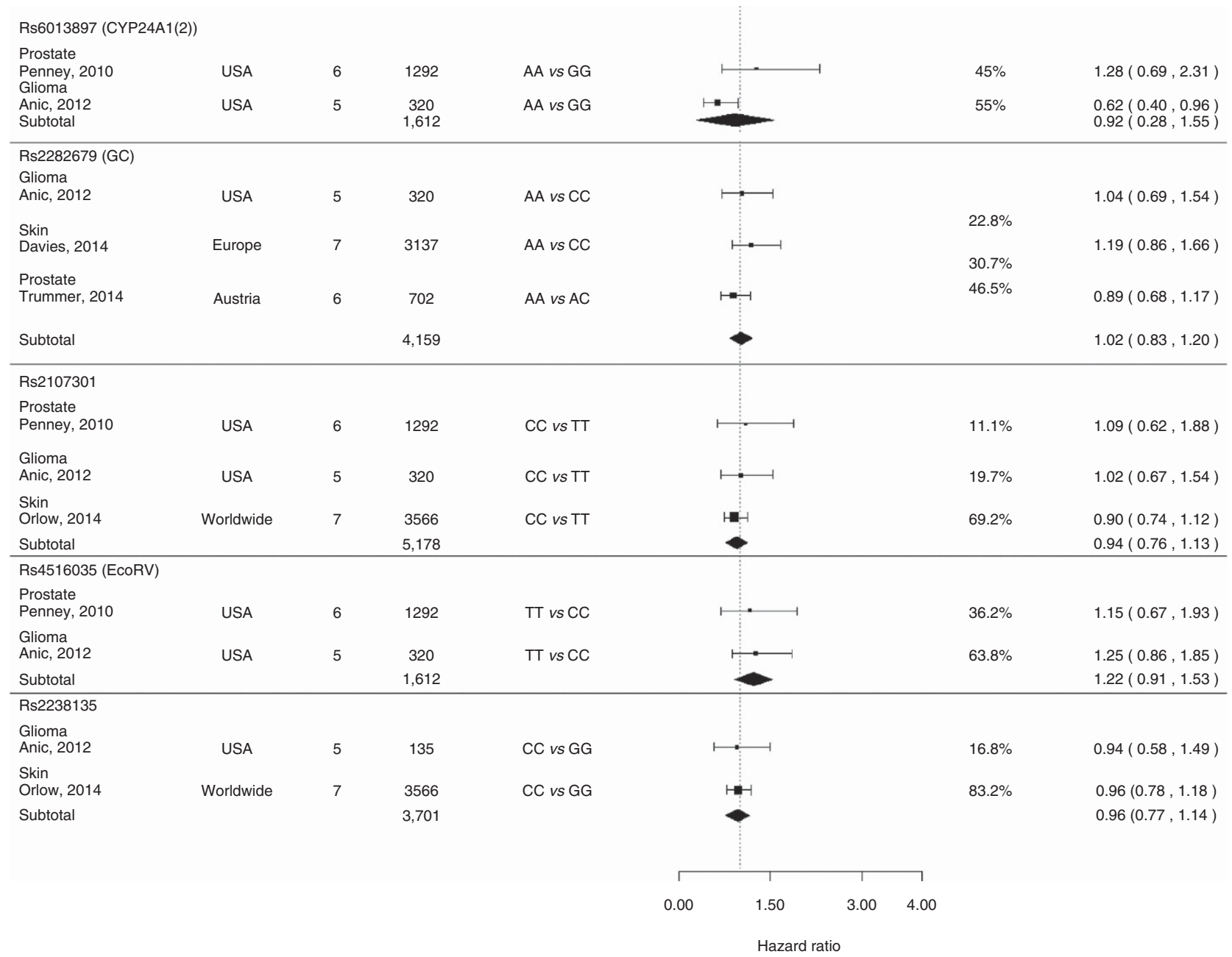

Figure 5. (Continued)

and that this interaction could have a critical role in cancer prognosis. Indeed, Han et al (Han et al, 2007) have shown an interaction between vitamin D intake and rs1544410 polymorphism on cancer risk, and we and others have previously shown a modification of the relationship between vitamin $\mathrm{D}$ intake or status and cancer outcome by other VDR variants, thus suggesting an interaction of genetic and environmental factors (Li et al, 2007; Theodoratou et al, 2008; Anderson et al, 2011; Zgaga et al, 2014). In conjunction with the strong associations observed for vitamin D status, evidence from genetic studies further supports an important role of vitamin $\mathrm{D}$ in cancer progression.

Few studies to date have analysed the associations between VDR or vitamin $\mathrm{D}$ pathway genetic variants and cancer outcomes, and no meta-analyses have been published to date. A review by Kostner et al (Kostner et al, 2009) concluded that associations between $V D R$ polymorphisms and cancer prognosis are strongest for prostate cancer (rs2228570), breast cancer (rs1544410, rs731236) malignant melanoma (rs1544410), and renal cell carcinoma (rs731236) but did not perform meta-analysis on these data.

Interestingly, Afzal et al (Afzal et al, 2014) have employed principles of Mendelian randomization in a study comprising 95766 participants and found that variation in genes involved in vitamin $D$ and 25OHD synthesis (DHCR7 and CYP2R1) were associated with both all-cause and cancer mortality, supporting a causal role of vitamin D. To date, there are no published findings from randomised controlled trials (RCT) assessing the effect of vitamin D supplementation on survival in cancer patients, although several ongoing trials (unfortunately only some of which have disease progression as an outcome) were identified (ClinicalTrials.gov, 2016). Meanwhile, the data on cancer mortality from RCTs conducted in the general population can offer some insight; most notably, a Cochrane review of randomised studies comparing vitamin $\mathrm{D}$ supplements to placebo identified a significant reduction in cancer mortality in those taking vitamin $\mathrm{D}$ supplements $(\mathrm{HR}=0.88,95 \% \mathrm{CI}=0.78-0.98$; Bjelakovic et al, 2014).

A major issue that is typically taken poor notice of in vitamin D meta-analyses-namely, a very large variability in vitamin D category definition amongst studies, is for the first time being highlighted and transparently shown in our review. Vitamin D categories differed in level as well as range-as a result, large heterogeneity in exposure definition occurred and study pointestimates are difficult to compare: it is, for example, unsurprising that the reported effect per $20 \mathrm{ng} \mathrm{ml}^{-1}$ is greater than effect per $5 \mathrm{ng} \mathrm{ml}^{-1}$ increase. Therefore, there is a need for a consensus in category definition and reporting of effect sizes: future original studies should report effect sizes using internationally agreed cutoffs, such as those given by the Institute of Medicine, solely or in addition to study-specific cutoff values chosen. Generally, variability in exposure categories results in a more heterogeneous estimates and is likely to increase statistical uncertainty and hence bias results towards the null. Nonetheless, our summary findings remain largely unchanged when the analysis was limited according to the difference in 25OHD between the compared groups.

There are some additional limitations of the present work. First, a number of relevant studies were published after the time limits stipulated in our search strategy and so are not included in our 
meta-analysis. Some such papers support the conclusions presented here (Brandstedt et al, 2016; Fang et al, 2016; Fanidi et al, 2016; Mondul et al, 2016; Orlow et al, 2016; Yao et al, 2016; Yuan et al, 2016), while others reported no association between circulating vitamin D and cancer outcome (Vashi et al, 2015; Ahn et al, 2016; Danilovic et al, 2016; McGovern et al, 2016).

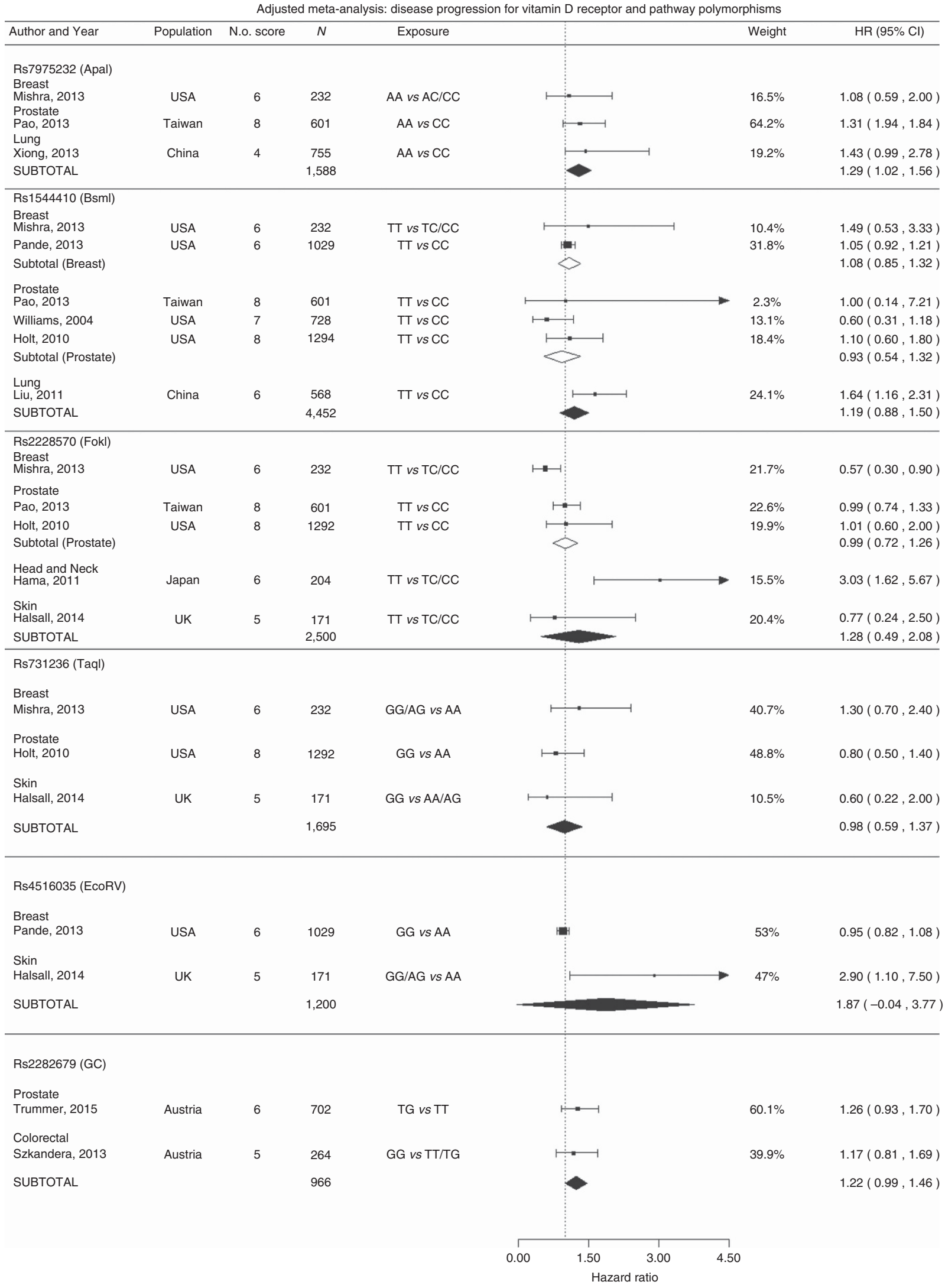

Figure 6. Cancer progression and vitamin D receptor polymorphisms and other vitamin D-related genetic variants: adjusted meta-analysis. $l^{2}$ for Apal: 0, Bsml prostate: 0.52, Bsml breast: 0.1, Bsml All: 0.61, Fokl Prostate: 0, Fokl All: 0.90, Taql all: 0, Rs4516035: 0.94, Rs22382679: 0. 
Second, various assays were used for $25 \mathrm{OHD}$ measurement in the different studies, while $25 \mathrm{OHD}$ was also sampled at variable timepoints, including pre-diagnosis, before treatment and after treatment, which may impact the results. Also, in disease progression studies, different outcome definitions were used for example, disease-free survival, local or distant recurrence.

In the present study, results for all cancers combined are given, in addition to site-specific findings, we yet fully acknowledge that cancer is a heterogeneous disease. However, numerous studies have shown involvement of vitamin $\mathrm{D}$ on key hallmarks of cancer, many of which are common to all cancers; preclinical studies demonstrate effects on cell cycle arrest, cell adhesion, differentiation, proliferation, tumour angiogenesis, and apoptosis in human cancer cell lines (Simboli-Campbell et al, 1997; Chen et al, 2000; Krishnan et al, 2003; Deeb et al, 2007; Kizildag et al, 2010; Hsu et al, 2011; Ting et al, 2012), while reduction in cancer proliferation has been shown in carcinogen-exposed rats (Mokady et al, 2000) and cancer phenotypes are more commonly observed in vitamin $\mathrm{D}$ receptor (VDR) knockout mice (Zheng et al, 2012). Nevertheless, the heterogeneity in pooled results between different cancer types and the small number of studies for certain cancers limits the strength of the current study in demonstrating an association between circulating 25-hydroxyvitamin $\mathrm{D}$ and total cancer survival.

Next, in reporting the impact of genetic variation on outcome, we acknowledge that ethnic differences in VDR variation exist, which might interfere with the findings from genetic studies, as ethnicity is directly linked to the skin type and vitamin D synthesis. Meanwhile, VDR variants may interact with circulating 25OHD to impact outcome, yet only a small number of studies examined these putative gene-environment interactions. Finally, we observed some evidence of heterogeneity and publication bias overall; however, findings from sensitivity analysis were highly consistent and supportive of main findings.

Despite these limitations, the present work includes a novel meta-analysis, investigating the association between vitamin D-related genetic variation and cancer outcome, in addition to a $\sim 50 \%$ larger meta-analysis of circulating $25 \mathrm{OHD}$ and cancer outcome compared to a previous review (Li et al, 2014). Moreover, stringent quality assessment of original studies and corresponding sensitivity analysis were conducted and strikingly inconsistent $25 \mathrm{OHD}$ category definitions were addressed in stratified analysis.

In conclusion, the consistent evidence across the studies presented in the current review demonstrates a clear and strong association between low baseline vitamin D levels and poorer cancer survival. The associations between vitamin D-related genetic variants and cancer survival support an interpretation that vitamin $\mathrm{D}$ may play an important role in influencing cancer outcome. However, a causal link cannot be conclusively established from observational studies; hence, well-designed and adequately powered RCTs are needed to evaluate the clinical application of vitamin $\mathrm{D}$ in augmenting standard follow-up and adjuvant chemotherapy regimens. Understanding the mechanism of action of genetic factors promises to provide further insight into biological determinants of response to treatment and could help inform prognosis.

\section{ACKNOWLEDGEMENTS}

The authors thank Professor John Haslett for significant statistical assistance. Part of this work relating to colorectal cancer only has been accepted for presentation at Association of Coloproctology of Great Britain and Ireland 2016 Annual Meeting at the EICC, Edinburgh from 4-6 July; title: 'Circulating 25-Hydroxyvitamin D and Vitamin D-Related Genetic Variation on Colorectal Cancer Outcome: A Systematic Review and Meta-Analysis'.

\section{CONFLICT OF INTEREST}

The authors declare no conflict of interest.

\section{REFERENCES}

Afzal S, Brondum-Jacobsen P, Bojesen SE, Nordestgaard BG (2014) Genetically low vitamin D concentrations and increased mortality: mendelian randomisation analysis in three large cohorts. Br Med J 349: g6330.

Ahn HY, Chung YJ, Park KY, Cho BY (2016) Serum 25-hydroxyvitamin D level does not affect the aggressiveness and prognosis of papillary thyroid cancer. Thyroid 26(3): 429-433.

Anderson LN, Cotterchio M, Cole DE, Knight JA (2011) Vitamin D-related genetic variants, interactions with vitamin $\mathrm{D}$ exposure, and breast cancer risk among Caucasian women in Ontario. Cancer Epidemiol Biomarkers Prev 20(8): 1708-1717.

Anderson PH, May BK, Morris HA (2003) Vitamin D metabolism: new concepts and clinical implications. Clin Biochem Rev 24(1): 13-26.

Anic GM, Thompson RC, Nabors LB, Olson JJ, Browning JE, Madden MH, Murtagh FR, Forsyth PA, Egan KM (2012) An exploratory analysis of common genetic variants in the vitamin $\mathrm{D}$ pathway including genome-wide associated variants in relation to glioma risk and outcome. Cancer Causes Control 23(9): 1443-1449.

Aref S, Ibrahim L, Azmy E (2013) Prognostic impact of serum 25-hydroxivitamin D [25(OH)D] concentrations in patients with lymphoid malignancies. Hematology 18(1): 20-25.

Azad AK, Bairati I, Qiu X, Huang H, Cheng D, Liu G, Meyer F, Adjei A, $\mathrm{Xu}$ W (2013) Genetic sequence variants in vitamin D metabolism pathway genes, serum vitamin $\mathrm{D}$ level and outcome in head and neck cancer patients. Int J Cancer 132(11): 2520-2527.

Bade B, Zdebik A, Wagenpfeil S, Graeber S, Geisel J, Vogt T, Reichrath J (2014) Low serum 25-hydroxyvitamin D concentrations are associated with increased risk for melanoma and unfavourable prognosis. PLoS One 9(12): e112863.

Berger U, McClelland RA, Wilson P, Greene GL, Haussler MR, Pike JW, Colston K, Easton D, Coombes RC (1991) Immunocytochemical determination of estrogen receptor, progesterone receptor, and 1,25dihydroxyvitamin D3 receptor in breast cancer and relationship to prognosis. Cancer Res 51(1): 239-244.

Bittenbring JT, Neumann F, Altmann B, Achenbach M, Reichrath J, Ziepert M, Geisel J, Regitz E, Held G, Pfreundschuh M (2014) Vitamin D deficiency impairs rituximab-mediated cellular cytotoxicity and outcome of patients with diffuse large B-cell lymphoma treated with but not without rituximab. J Clin Oncol 32(29): 3242-3248.

Bjelakovic G, Gluud LL, Nikolova D, Whitfield K, Wetterslev J, Simonetti RG, Bjelakovic M, Gluud C (2014) Vitamin D supplementation for prevention of mortality in adults. Cochrane Database Syst Rev 1: CD007470CD007470.

Bouillon R, Van Schoor NM, Gielen E, Boonen S, Mathieu C, Vanderschueren D, Lips P (2013) Optimal vitamin D status: a critical analysis on the basis of evidence-based medicine. J Clin Endocrinol Metab 98(8): E1283-E1304.

Brandstedt J, Almquist M, Manjer J, Malm J (2016) Vitamin D, PTH, and calcium in relation to survival following prostate cancer. Cancer Causes Control 27(5): 669-677.

Chen TC, Schwartz GG, Burnstein KL, Lokeshwar BL, Holick MF (2000) The in vitro evaluation of 25-hydroxyvitamin D3 and 19-nor-1alpha,25dihydroxyvitamin D2 as therapeutic agents for prostate cancer. Clin Cancer Res 6(3): 901-908.

Cho M, Peddi PF, Ding K, Chen L, Thomas D, Wang J, Lockhart AC, Tan B, Wang-Gillam A (2013) Vitamin D deficiency and prognostics among patients with pancreatic adenocarcinoma. J Transl Med 11: 206.

Clark AS, Chen J, Kapoor S, Friedman C, Mies C, Esserman L, DeMichele A, Investigators IS (2014) Pretreatment vitamin D level and response to neoadjuvant chemotherapy in women with breast cancer on the I-SPY trial (CALGB 150007/150015/ACRIN6657). Cancer Med 3: 693-701.

Cochrane (2011) Cochrane Handbook for Systematic Reviews of Interventions. Version 5.1.0, Higgins JPT GS (ed) The Cochrane Collaboration.

Crew KD, Shane E, Cremers S, McMahon DJ, Irani D, Hershman DL (2009) High prevalence of vitamin D deficiency despite supplementation in 
premenopausal women with breast cancer undergoing adjuvant chemotherapy. J Clin Oncol 27(13): 2151-2156.

CRUK (2015) Worldwide Cancer Mortality Statistics, Vol. 2015. Available at: http://www.cancerresearchuk.org/health-professional/cancer-statistics/ worldwide-cancer/mortality.

Davies JR, Field S, Randerson-Moor J, Harland M, Kumar R, Anic GM, Nagore E, Hansson J, Hoeiom V, Joensson G, Gruis NA, Park JY, Guan J, Rachakonda PS, Wendt J, Pjanova D, Puig S, Schadendorf D, Okamoto I, Olsson H, Affleck P, Garcia-Casado Z, Anton Puig-Butille J, Stratigos AJ, Kodela E, Donina S, Sucker A, Hosen I, Egan KM, Barrett JH, van Doorn R, Bishop DT, Newton-Bishop J (2014) An inherited variant in the gene coding for vitamin D-binding protein and survival from cutaneous melanoma: a BioGenoMEL study.. Pigment Cell Melanoma Res 27(2): 234-243.

Danilovic DL, Ferraz-de-Souza B, Fabri AW, Santana NO, Kulcsar MA, Cernea CR, Marui S, Hoff AO (2016) 25-Hydroxyvitamin D and TSH as risk factors or prognostic markers in thyroid carcinoma. PLoS One 11(10): e0164550.

Deeb KK, Trump DL, Johnson CS (2007) Vitamin D signalling pathways in cancer: potential for anticancer therapeutics. Nat Rev Cancer 7(9): 684-700.

Der T, Bailey BA, Youssef D, Manning T, Grant WB, Peiris AN (2014) Vitamin D and prostate cancer survival in veterans. Mil Med 179(1): 81-84.

Dickinson AM, Pearce KF, Norden J, O'Brien SG, Holler E, Bickeböller H, Balavarca Y, Rocha V, Kolb HJ, Hromadnikova I, Sedlacek P, Niederwieser D, Brand R, Ruutu T, Apperley J, Szydlo R, Goulmy E, Siegert W, de Witte T, Gratwohl A (2010) Impact of genomic risk factors on outcome after hematopoietic stem cell transplantation for patients with chronic myeloid leukemia. Haematologica 95(6): 922-927.

Ditsch N, Toth B, Mayr D, Lenhard M, Gallwas J, Weissenbacher T, Dannecker C, Friese K, Jeschke U (2012) The association between vitamin $\mathrm{D}$ receptor expression and prolonged overall survival in breast cancer. J Histochem Cytochem 60(2): 121-129.

Drake MT, Maurer MJ, Link BK, Habermann TM, Ansell SM, Micallef IN, Kelly JL, Macon WR, Nowakowski GS, Inwards DJ, Johnston PB, Singh RJ, Allmer C, Slager SL, Weiner GJ, Witzig TE, Cerhan JR (2010) Vitamin D insufficiency and prognosis in non-Hodgkin's lymphoma. J Clin Oncol 28(27): 4191-4198.

EMBASE (2015) EMBASE, Vol. 2015. Available at: https://www.embase.com.

Fakih MG, Trump DL, Johnson CS, Tian L, Muindi J, Sunga AY (2009) Chemotherapy is linked to severe vitamin D deficiency in patients with colorectal cancer. Int J Colorectal Dis 24(2): 219-224.

Fang F, Kasperzyk JL, Shui I, Hendrickson W, Hollis BW, Fall K, Ma J, Gaziano JM, Stampfer MJ, Mucci LA, Giovannucci E (2011) Prediagnostic plasma vitamin D metabolites and mortality among patients with prostate cancer. PLoS One 6(4): e18625.

Fang S, Sui D, Wang Y, Liu H, Chiang YJ, Ross MI, Gershenwald JE, Cormier JN, Royal RE, Lucci A, Wargo J, Hu MI, Gardner JM, Reveille JD, Bassett RL, Wei Q, Amos CI, Lee JE (2016) Association of vitamin D levels with outcome in patients with melanoma after adjustment for C-reactive protein. J Clin Oncol 34(15): 1741-1747.

Fanidi A, Muller DC, Midttun O, Ueland PM, Vollset SE, Relton C, Vineis P, Weiderpass E, Skeie G, Brustad M, Palli D, Tumino R, Grioni S, Sacerdote C, Bueno-de-Mesquita HB, Peeters PH, Boutron-Ruault MC, Kvaskoff M, Cadeau C, Huerta JM, Sanchez MJ, Agudo A, Lasheras C, Quiros JR, Chamosa S, Riboli E, Travis RC, Ward H, Murphy N, Khaw KT, Trichopoulou A, Lagiou P, Papatesta EM, Boeing H, Kuehn T, Katzke V, Steffen A, Johansson A, Brennan P, Johansson M (2016) Circulating vitamin $\mathrm{D}$ in relation to cancer incidence and survival of the head and neck and oesophagus in the EPIC cohort. Sci Rep 6: 36017.

Fedirko V, Riboli E, Tjonneland A, Ferrari P, Olsen A, Bueno-de-Mesquita HB, van Duijnhoven FJB, Norat T, EHJM Jansen, Dahm CC, Overvad K, Boutron-Ruault M-C, Clavel-Chapelon F, Racine A, Lukanova A, Teucher B, Boeing H, Aleksandrova K, Trichopoulou A, Benetou V, Trichopoulos D, Grioni S, Vineis P, Panico S, Palli D, Tumino R, Siersema PD, Peeters PH, Skeie G, Brustad M, Chirlaque M-D, Barricarte A, Ramon Quiros J, Jose Sanchez M, Dorronsoro M, Bonet C, Palmqvist R, Hallmans G, Key TJ, Crowe F, Khaw K-T, Wareham N, Romieu I, McKay J, Wark PA, Romaguera D, Jenab M (2012) Prediagnostic 25-hydroxyvitamin D, VDR and CASR polymorphisms, and survival in patients with colorectal cancer in western European populations. Cancer Epidemiol Biomarkers Prev 21(4): 582-593.
Field S, Elliott F, Randerson-Moor J, Kukalizch K, Barrett JH, Bishop DT, Newton-Bishop JA (2013) Do vitamin A serum levels moderate outcome or the protective effect of vitamin D on outcome from malignant melanoma? Clin Nutr 32(6): 1012-1016.

Finkelmeier F, Kronenberger B, Koeberle V, Bojunga J, Zeuzem S, Trojan J, Piiper A, Waidmann O (2014) Severe 25-hydroxyvitamin D deficiency identifies a poor prognosis in patients with hepatocellular carcinoma - a prospective cohort study. Aliment Pharmacol Ther 39(10): $1204-1212$.

Flugge J, Krusekopf S, Goldammer M, Osswald E, Terhalle W, Malzahn U, Roots I (2007) Vitamin D receptor haplotypes protect against development of colorectal cancer. Eur J Clin Pharmacol 63(11): 997-1005.

Furuya Y, Akakura K, Masai M, Ito H (1999) Vitamin D receptor gene polymorphism in Japanese patients with prostate cancer. Endocr J 46(3): $467-470$.

Goode EL, Dunning AM, Kuschel B, Healey CS, Day NE, Ponder BAJ, Easton DF, Pharoah PPD (2002) Effect of germ-line genetic variation on breast cancer survival in a population-based study. Cancer Res 62(11): 3052-3057.

Goodwin PJ, Ennis M, Pritchard KI, Koo J, Hood N (2009) Prognostic effects of 25-hydroxyvitamin D levels in early breast cancer. J Clin Oncol 27(23): 3757-3763.

Gugatschka M, Kiesler K, Obermayer-Pietsch B, Groselj-Strele A, Griesbacher A, Friedrich G (2011) Vitamin D status is associated with disease-free survival and overall survival time in patients with squamous cell carcinoma of the upper aerodigestive tract. Eur Arch Otorhinolaryngol 268(8): 1201-1204.

Gupta D, Trukova K, Popiel B, Lammersfeld C, Vashi PG (2015) The association between pre-treatment serum 25 -hydroxyvitamin $\mathrm{D}$ and survival in newly diagnosed stage IV prostate cancer. PLoS One 10(3): e0119690.

Halsall JA, Osborne JE, Potter L, Pringle JH, Hutchinson PE (2004) A novel polymorphism in the $1 \mathrm{~A}$ promoter region of the vitamin $\mathrm{D}$ receptor is associated with altered susceptibilty and prognosis in malignant melanoma. Br J Cancer 91(4): 765-770.

Hama T, Norizoe C, Suga H, Mimura T, Kato T, Moriyama H, Urashima M (2011) Prognostic significance of vitamin D receptor polymorphisms in head and neck squamous cell carcinoma. PLoS One 6(12): e29634.

Han J, Colditz GA, Hunter DJ (2007) Polymorphisms in the MTHFR and VDR genes and skin cancer risk. Carcinogenesis 28(2): 390-397.

Hansson MEA, Norlin A-C, Omazic B, Wikstrom A-C, Bergman P, Winiarski J, Remberger M, Sundin M (2014) Vitamin D levels affect outcome in pediatric hematopoietic stem cell transplantation. Biol Blood Marrow Transplant 20(10): 1537-1543.

Hatse S, Lambrechts D, Verstuyf A, Smeets A, Brouwers B, Vandorpe T, Brouckaert O, Peuteman G, Laenen A, Verlinden L, Kriebitzsch C, Dieudonne AS, Paridaens R, Neven P, Christiaens MR, Bouillon R, Wildiers H (2012) Vitamin D status at breast cancer diagnosis: correlation with tumor characteristics, disease outcome, and genetic determinants of vitamin D insufficiency. Carcinogenesis 33(7): 1319-1326.

Heist RS, Zhou W, Wang Z, Liu G, Neuberg D, Su L, Asomaning K, Hollis BW, Lynch TJ, Wain JC, Giovannucci E, Christiani DC (2008) Circulating 25-hydroxyvitamin D, VDR polymorphisms, and survival in advanced non-small-cell lung cancer. J Clin Oncol 26(34): 5596-5602.

Hendrickson WK, Flavin R, Kasperzyk JL, Fiorentino M, Fang F, Lis R, Fiore C, Penney KL, Ma J, Kantoff PW, Stampfer MJ, Loda M, Mucci LA, Giovannucci E (2011) Vitamin D receptor protein expression in tumor tissue and prostate cancer progression. J Clin Oncol 29(17): 2378-2385.

Higgins JP, Thompson SG, Deeks JJ, Altman DG (2003) Measuring inconsistency in meta-analyses. Bmj 327(7414): 557-560.

Holick MF (2007) Vitamin D deficiency. N Engl J Med 357(3): 266-281.

Holt SK, Kolb S, Fu R, Horst R, Feng Z, Stanford JL (2013) Circulating levels of 25-hydroxyvitamin D and prostate cancer prognosis. Cancer Epidemiol 37(5): 666-670.

Holt SK, Kwon EM, Koopmeiners JS, Lin DW, Feng Z, Ostrander EA, Peters U, Stanford JL (2010) Vitamin D pathway gene variants and prostate cancer prognosis. Prostate 70(13): 1448-1460.

Hsu JW, Yasmin-Karim S, King MR, Wojciechowski JC, Mickelsen D, Blair ML, Ting HJ, Ma WL, Lee YF (2011) Suppression of prostate cancer cell rolling and adhesion to endothelium by 1alpha,25-dihydroxyvitamin D3. Am J Pathol 178(2): 872-880. 
Ingles SA, Wang J, Coetzee GA, Lee ER, Frankl HD, Haile RW (2001) Vitamin $\mathrm{D}$ receptor polymorphisms and risk of colorectal adenomas (United States). Cancer Causes Control 12(7): 607-614.

Jacobs ET, Thomson CA, Flatt SW, Al-Delaimy WK, Hibler EA, Jones LA, LeRoy EC, Newman VA, Parker BA, Rock CL, Pierce JP (2011) Vitamin D and breast cancer recurrence in the Women's Healthy Eating and Living (WHEL) study. Am J Clin Nutr 93(1): 108-117.

JISC (2015) Web of Science. Available at: http://www.webofknowledge.com. Kelly D, Theodoratou E, Farrington S, Fraser R, Campbell H, Dunlop MG, Zgaga L (2015) The Contributions of adjusted ambient UVB at the place of residence and other determinants to serum 25-hydroxyvitamin d concentrations. Br J Dermatol 174(5): 1068-1078.

Kelly JL, Salles G, Goldman B, Fisher RI, Brice P, Press O, Casasnovas O, Maloney DG, Soubeyran P, Rimsza L, Haioun C, Xerri L, LeBlanc M, Tilly H, Friedberg JW (2015) Low serum vitamin D levels are associated with inferior survival in follicular lymphoma: aprospective evaluation in SWOG and LYSA studies. J Clin Oncol 33(13): 1482-1490.

Kim H, Kang HJ, Kim HJ, Jang MK, Kim NH, Oh Y, Han B-D, Choi J-Y, Kim CW, Lee JW, Park KD, Shin HY, Ahn HS (2012) Pharmacogenetic analysis of pediatric patients with acute lymphoblastic leukemia: a possible association between survival rate and ITPA polymorphism. PLoS One 7(9): e45558.

Kim HJ, Lee YM, Ko BS, Lee JW, Yu JH, Son BH, Gong G-Y, Kim SB, Ahn SH (2011) Vitamin D deficiency is correlated with poor outcomes in patients with luminal-type breast cancer. Ann Surg Oncol 18(7): 1830-1836.

Kizildag S, Ates H, Kizildag S (2010) Treatment of K562 cells with 1,25dihydroxyvitamin D3 induces distinct alterations in the expression of apoptosisrelated genes BCL2, BAX, BCLXL, and p21. Ann Hematol 89(1): 1-7.

Kostner K, Denzer N, Muller CS, Klein R, Tilgen W, Reichrath J (2009) The relevance of vitamin D receptor (VDR) gene polymorphisms for cancer: a review of the literature. Anticancer Res 29(9): 3511-3536.

Krishnan AV, Peehl DM, Feldman D (2003) Inhibition of prostate cancer growth by vitamin D: Regulation of target gene expression. J Cell Biochem 88(2): 363-371.

Lee HJ, Muindi JR, Tan W, Hu Q, Wang D, Liu S, Wilding GE, Ford LA, Sait SNJ, Block AW, Adjei AA, Barcos M, Griffiths EA, Thompson JE, Wang ES, Johnson CS, Trump DL, Wetzler M (2014) Low 25(OH) vitamin D-3 levels are associated with adverse outcome in newly diagnosed, intensively treated adult acute myeloid leukemia. Cancer 120(4): 521-529.

Li H, Stampfer MJ, Hollis JB, Mucci LA, Gaziano JM, Hunter D, Giovannucci EL, Ma J (2007) A prospective study of plasma vitamin D metabolites, vitamin D receptor polymorphisms, and prostate cancer. PLoS Med 4(3): e103.

Li M, Chen P, Li J, Chu R, Xie D, Wang H (2014) Review: the impacts of circulating 25-hydroxyvitamin D levels on cancer patient outcomes: a systematic review and meta-analysis. J Clin Endocrinol Metab 99(7): 2327-2336

Lim ST, Jeon YW, Suh YJ (2015) Association between alterations in the serum 25-hydroxyvitamin d status during follow-up and breast cancer patient prognosis. Asian Pac J Cancer Prev 16(6): 2507-2513.

Liu Y, Chen W, Hu Z-b Xu L, Shu Y-q Pan S-y, Dai J-c, Jin G-f, Ma H-x Shen H-b (2011) Plasma vitamin D levels and vitamin D receptor polymorphisms are associated with survival of non-small cell lung cancer. Chin J Cancer Res 23(1): 33-37.

Lohmann AE, Chapman J-AW, Burnell MJ, Levine MN, Tsvetkova E, Pritchard KI, Gelmon KA, O’Brien P, Han L, Rugo HS, Albain KS, Perez EA, Vandenberg TA, Chalchal HI, Sawhney RPS, Shepherd LE, Goodwin PJ (2015) Prognostic associations of 25 hydroxy vitamin D in NCIC CTG MA.21, a phase III adjuvant randomized clinical trial of three chemotherapy regimens in high-risk breast cancer. Breast Cancer Res Treat 150(3): 605-611.

Lowe LC, Guy M, Mansi JL, Peckitt C, Bliss J, Wilson RG, Colston KW (2005) Plasma 25-hydroxy vitamin D concentrations, vitamin D receptor genotype and breast cancer risk in a UK Caucasian population. Eur J Cancer 41(8): 1164-1169.

Lundin AC, Soderkvist P, Eriksson B, Bergman-Jungestrom M, Wingren S Grp SESBC (1999) Association of breast cancer progression with a vitamin D receptor gene polymorphism. Cancer Res 59(10): 2332-2334

McGovern EM, Lewis ME, Niesley ML, Huynh N, Hoag JB (2016) Retrospective analysis of the influence of 25 -hydroxyvitamin $\mathrm{D}$ on disease progression and survival in pancreatic cancer. Nutr J 15: 17.
Meyer F, Liu G, Douville P, Samson E, Xu W, Adjei A, Bairati I (2011) Dietary vitamin $\mathrm{D}$ intake and serum 25 -hydroxyvitamin $\mathrm{D}$ level in relation to disease outcomes in head and neck cancer patients. Int J Cancer 128(7): 1741-1746.

Mezawa H, Sugiura T, Watanabe M, Norizoe C, Takahashi D, Shimojima A, Tamez S, Tsutsumi Y, Yanaga K, Urashima M (2010) Serum vitamin D levels and survival of patients with colorectal cancer: post-hoc analysis of a prospective cohort study. BMC Cancer 10: 347.

Mishra DK, Wu Y, Sarkissyan M, Sarkissyan S, Chen Z, Shang X, Ong M, Heber D, Koeffler HP, Vadgama JV (2013) Vitamin D receptor gene polymorphisms and prognosis of breast cancer among African-American and Hispanic women. PLoSOne 8(3): e57967.

Moher D, Liberati A, Tetzlaff J, Altman DG, Group P (2009) Preferred reporting items for systematic reviews and meta-analyses: the PRISMA statement. PLoS Med 6(7): e1000097.

Mokady E, Schwartz B, Shany S, Lamprecht SA (2000) A protective role of dietary vitamin D3 in rat colon carcinogenesis. Nutr Cancer 38(1): 65-73.

Mondul AM, Weinstein SJ, Moy KA, Mannisto S, Albanes D (2016) Circulating 25-hydroxyvitamin D and prostate cancer survival. Cancer Epidemiol Biomarkers Prev 25(4): 665-669.

Muller DC, Scelo G, Zaridze D, Janout V, Holcatova I, Navratilova M, Mates D, Midttun O, Ueland PM, Brennan P, Johansson M (2015) Circulating 25-hydroxyvitamin D-3 and survival after diagnosis with kidney cancer. Cancer Epidemiol Biomarkers Prev 24(8): 1277-1281.

NCBI (2015) PUBMED, Information NNCfB (ed). National Center for Biotechnology Information, vol 2015. Available at: PUBMED. https:// www.ncbi.nlm.nih.gov/pubmed.

Newton-Bishop JA, Beswick S, Randerson-Moor J, Chang YM, Affleck P, Elliott F, Chan M, Leake S, Karpavicius B, Haynes S, Kukalizch K, Whitaker L, Jackson S, Gerry E, Nolan C, Bertram C, Marsden J, Elder DE, Barrett JH, Bishop DT (2009) Serum 25-hydroxyvitamin D3 levels are associated with breslow thickness at presentation and survival from melanoma. J Clin Oncol 27(32): 5439-5444.

Newton-Bishop JA, Davies JR, Latheef F, Randerson-Moor J, Chan M, Gascoyne J, Waseem S, Haynes S, O'Donovan C, Bishop DT (2015) 25Hydroxyvitamin D2 /D3 levels and factors associated with systemic inflammation and melanoma survival in the Leeds Melanoma Cohort. Int J Cancer 136(12): 2890-2899.

Ng K, Meyerhardt JA, Wu K, Feskanich D, Hollis BW, Giovannucci EL, Fuchs CS (2008) Circulating 25-hydroxyvitamin D levels and survival in patients with colorectal cancer. J Clin Oncol 26(18): 2984-2991.

Ng K, Sargent DJ, Goldberg RM, Meyerhardt JA, Green EM, Pitot HC, Hollis BW, Pollak MN, Fuchs CS (2011) Vitamin D status in patients with stage IV colorectal cancer: findings from intergroup trial N9741. J Clin Oncol 29(12): 1599-1606.

Nurnberg B, Graber S, Gartner B, Geisel J, Pfohler C, Schadendorf D, Tilgen W, Reichrath J (2009) Reduced serum 25-hydroxyvitamin D levels in stage IV melanoma patients. Anticancer Res 29(9): 3669-3674.

Obara W, Suzuki Y, Kato K, Tanji S, Konda R, Fujioka T (2007) Vitamin D receptor gene polymorphisms are associated with increased risk and progression of renal cell carcinoma in a Japanese population. Int $J$ Urol 14(6): 483-487.

Obermannova R, Dusek L, Greplova K, Jarkovsky J, Sterba J, Vyzula R, Demlova R, Zdrazilova-Dubska L, Valik D (2015) Time-course pattern of blood 25-hydroxycholecalciferol is a significant predictor of survival outcome in metastatic colorectal cancer: a clinical practice-based study. Neoplasma 62(6): 958-965.

Orlow I, Reiner AS, Thomas NE, Roy P, Kanetsky PA, Luo L, Paine S, Armstrong BK, Kricker A, Marrett LD, Rosso S, Zanetti R, Gruber SB, Anton-Culver H, Gallagher RP, Dwyer T, Busam K, Begg CB, Berwick M, Group GEMS (2016) Vitamin D receptor polymorphisms and survival in patients with cutaneous melanoma: a population-based study. Carcinogenesis 37(1): 30-38.

Pande M, Thompson PA, Do K-A, Sahin AA, Amos CI, Frazier ML, Bondy ML, Brewster AM (2013) Genetic variants in the vitamin D pathway and breast cancer disease-free survival. Carcinogenesis 34(3): 587-594.

Pao J-B, Yang Y-P, Huang C-N, Huang S-P, Hour T-C, Chang T-Y, Lan Y-H, Lu T-L, Lee H-Z, Juang S-H, Huang C-Y, Bao B-Y (2013) Vitamin D receptor gene variants and clinical outcomes after androgen-deprivation therapy for prostate cancer. World JUrol 31(2): 281-287.

Pardanani A, Drake MT, Finke C, Lasho TL, Rozell SA, Jimma T, Tefferi A (2011) Vitamin D insufficiency in myeloproliferative neoplasms and 
myelodysplastic syndromes: clinical correlates and prognostic studies. Am J Hematol 86(12): 1013-1016.

Peiris AN, Bailey BA, Manning T (2013) Relationship of vitamin D monitoring and status to bladder cancer survival in veterans. South Med J 106(2): 126-130.

Penney KL, Pyne S, Schumacher FR, Sinnott JA, Mucci LA, Kraft PL, Ma J, Oh WK, Kurth T, Kantoff PW, Giovannucci EL, Stampfer MJ, Hunter DJ, Freedman ML (2010) Genome-wide association study of prostate cancer mortality. Cancer Epidemiol Biomarkers Prev 19(11): 2869-2876.

Perna L, Butterbach K, Haug U, Schoettker B, Mueller H, Arndt V, Holleczek B, Burwinkel B, Brenner H (2013a) Vitamin D receptor genotype rs731236 (Taq1) and breast cancer prognosis. Cancer Epidemiol Biomarkers Prev 22(3): 437-442.

Perna L, Hoffmeister M, Schoettker B, Arndt V, Haug U, Holleczek B, Burwinkel B, Ordonez-Mena JM, Brenner H (2013b) Vitamin D receptor polymorphism and colorectal cancer-specific and all-cause mortality. Cancer Epidemiol 37(6): 905-907.

R Core Team (2013) R: A language and environment for statistical computing. R Foundation for Statistical Computing, Vienna, Austria. URL http:// www.R-project.org/.

Ramagopalan SV, Heger A, Berlanga AJ, Maugeri NJ, Lincoln MR, Burrell A, Handunnetthi L, Handel AE, Disanto G, Orton SM, Watson CT, Morahan JM, Giovannoni G, Ponting CP, Ebers GC, Knight JC (2010) A ChIP-seq defined genome-wide map of vitamin D receptor binding: associations with disease and evolution. Genome Res 20(10): 1352-1360.

Ren C, Qiu MZ, Wang DS, Luo HY, Zhang DS, Wang ZQ, Wang FH, Li YH, Zhou ZW, Xu RH (2012) Prognostic effects of 25-hydroxyvitamin D levels in gastric cancer. J Transl Med 10: 16.

Samimi M, Touze A, Laude H, Le Bidre E, Arnold F, Carpentier A, Gardair C, Carlotti A, Maubec E, Dupin N, Aubin F, Avril MF, Rozenberg F, Avenel-Audran M, Guyetant S, Lorette G, Machet L, Coursaget P (2014) Vitamin D deficiency is associated with greater tumor size and poorer outcome in Merkel cell carcinoma patients. J Eur Acad Dermatol Venereol 28(3): 298-308.

Serrano D, Gnagnarella P, Raimondi S, Gandini S (2016) Meta-analysis on vitamin D receptor and cancer risk: focus on the role of TaqI, ApaI, and Cdx2 polymorphisms. Eur J Cancer Prev 25(1): 85-96.

Shanafelt TD, Drake MT, Maurer MJ, Allmer C, Rabe KG, Slager SL, Weiner GJ, Call TG, Link BK, Zent CS, Kay NE, Hanson CA, Witzig TE, Cerhan JR (2011) Vitamin D insufficiency and prognosis in chronic lymphocytic leukemia. Blood 117(5): 1492-1498.

Silvagno F, Poma CB, Realmuto C, Ravarino N, Ramella A, Santoro N, D’Amelio P, Fuso L, Pescarmona G, Zola P (2010) Analysis of vitamin D receptor expression and clinical correlations in patients with ovarian cancer. Gynecol Oncol 119(1): 121-124.

Simboli-Campbell M, Narvaez CJ, van Weelden K, Tenniswood M, Welsh J (1997) Comparative effects of 1,25(OH)2D3 and EB1089 on cell cycle kinetics and apoptosis in MCF-7 breast cancer cells. Breast Cancer Res Treat 42(1): 31-41.

Staal A, van Wijnen AJ, Birkenhager JC, Pols HA, Prahl J, DeLuca H, Gaub MP, Lian JB, Stein GS, van Leeuwen JP, Stein JL (1996) Distinct conformations of vitamin D receptor/retinoid X receptor-alpha heterodimers are specified by dinucleotide differences in the vitamin D-responsive elements of the osteocalcin and osteopontin genes. Mol Endocrinol 10(11): 1444-1456.

Sterne JA, Egger M (2001) Funnel plots for detecting bias in meta-analysis: guidelines on choice of axis. J Clin Epidemiol 54(10): 1046-1055.

Symons MJ, Moore DT (2002) Hazard rate ratio and prospective epidemiological studies. J Clin Epidemiol 55(9): 893-899.

Szkandera J, Absenger G, Pichler M, Stotz M, Langsenlehner T, Samonigg H, Renner W, Gerger A (2013) Association of common gene variants in vitamin D modulating genes and colon cancer recurrence. J Cancer Res Clin Oncol 139(9): 1457-1464.

Tamez S, Norizoe C, Ochiai K, Takahashi D, Shimojima A, Tsutsumi Y, Yanaihara N, Tanaka T, Okamoto A, Urashima M (2009) Vitamin D receptor polymorphisms and prognosis of patients with epithelial ovarian cancer. Br J Cancer 101(12): 1957-1960.

Taylor JA, Hirvonen A, Watson M, Pittman G, Mohler JL, Bell DA (1996) Association of prostate cancer with vitamin $\mathrm{D}$ receptor gene polymorphism. Cancer Res 56(18): 4108-4110.

Theodoratou E, Farrington SM, Tenesa A, McNeill G, Cetnarskyj R, Barnetson RA, Porteous ME, Dunlop MG, Campbell H (2008)
Modification of the inverse association between dietary vitamin D intake and colorectal cancer risk by a FokI variant supports a chemoprotective action of Vitamin D intake mediated through VDR binding. Int $J$ Cancer 123(9): 2170-2179.

Theodoratou E, Tzoulaki I, Zgaga L, Ioannidis JP (2014) Vitamin D and multiple health outcomes: umbrella review of systematic reviews and metaanalyses of observational studies and randomised trials. BMJ 348: g2035.

Ting HJ, Yasmin-Karim S, Yan SJ, Hsu JW, Lin TH, Zeng W, Messing J, Sheu TJ, Bao BY, Li WX, Messing E, Lee YF (2012) A positive feedback signaling loop between ATM and the vitamin D receptor is critical for cancer chemoprevention by vitamin D. Cancer Res 72(4): 958-968.

Tretli S, Hernes E, Berg JP, Hestvik UE, Robsahm TE (2009) Association between serum $25(\mathrm{OH}) \mathrm{D}$ and death from prostate cancer. $\mathrm{Br} J$ Cancer 100(3): 450-454.

Tretli S, Schwartz GG, Torjesen PA, Robsahm TE (2012) Serum levels of 25-hydroxyvitamin D and survival in Norwegian patients with cancer of breast, colon, lung, and lymphoma: a population-based study. Cancer Causes Control 23(2): 363-370.

Trummer O, Langsenlehner U, Krenn-Pilko S, Pieber TR, Obermayer-Pietsch B, Gerger A, Renner W, Langsenlehner T (2015) Vitamin D and prostate cancer prognosis: a Mendelian randomization study. World J Urol 34(4): 607-611.

Turner AM, McGowan L, Millen A, Rajesh P, Webster C, Langman G, Rock G, Tachibana I, Tomlinson MG, Berditchevski F, Naidu B (2013) Circulating DBP level and prognosis in operated lung cancer: an exploration of pathophysiology. Eur Respir J 41(2): 410-416.

Turna A, Pekcolaklar A, Metin M, Yaylim I, Gurses A (2012) The effect of season of operation on the survival of patients with resected non-small cell lung cancer. Interact Cardiovasc Thorac Surg 14(2): 151-155.

Uitterlinden AG, Fang Y, Van Meurs JB, Pols HA, Van Leeuwen JP (2004) Genetics and biology of vitamin D receptor polymorphisms. Gene 338(2): 143-156.

Vashi PG, Edwin P, Popiel B, Gupta D (2015) The relationship between circulating 25-hydroxyvitamin D and survival in newly diagnosed advanced non-small-cell lung cancer. BMC Cancer 15: 1012.

Van Loon K, Owzar K, Jiang C, Kindler HL, Mulcahy MF, Niedzwiecki D, O’Reilly EM, Fuchs C, Innocenti F, Venook AP. Alliance Clinical Trials O (2014) 25-Hydroxyvitamin D levels and survival in advanced pancreatic cancer: findings from CALGB 80303 (Alliance). J Natl Cancer Inst 106(8): pii: dju185.

Viechtbauer W, Cheung MW (2010) Outlier and influence diagnostics for meta-analysis. Res Synth Methods 1(2): 112-125.

Villasenor A, Ballard-Barbash R, Ambs A, Bernstein L, Baumgartner K, Baumgartner R, Ulrich CM, Hollis BW, McTiernan A, Neuhouser ML (2013) Associations of serum 25-hydroxyvitamin D with overall and breast cancer-specific mortality in a multiethnic cohort of breast cancer survivors. Cancer Causes Control 24(4): 759-767.

Vrieling A, Hein R, Abbas S, Schneeweiss A, Flesch-Janys D, Chang-Claude J (2011) Serum 25-hydroxyvitamin D and postmenopausal breast cancer survival: a prospective patient cohort study. Breast Cancer Res 13(4): R74.

Vrieling A, Seibold P, Johnson TS, Heinz J, Obi N, Kaaks R, Flesch-Janys D, Chang-Claude J (2014) Circulating 25-hydroxyvitamin D and postmenopausal breast cancer survival: Influence of tumor characteristics and lifestyle factors? Int J Cancer 134(12): 2972-2983.

Walentowicz-Sadlecka M, Grabiec M, Sadlecki P, Gotowska M, Walentowicz P, Krintus M, Mankowska-Cyl A, Sypniewska G (2012) $25(\mathrm{OH}) \mathrm{D} 3$ in patients with ovarian cancer and its correlation with survival. Clin Biochem 45(18): 1568-1572.

Webb PM, de Fazio A, Protani MM, Ibiebele TI, Nagle CM, Brand AH, Blomfield PI, Grant P, Perrin LC, Neale RE. Australian Ovarian Cancer Study G (2015) Circulating 25-hydroxyvitamin D and survival in women with ovarian cancer. Am J Clin Nutr 102(1): 109-114.

Wells G, Shea B, O'connell D, Peterson J, Welch V, Losos M, Tugwell P (2000) The Newcastle-Ottawa Scale (NOS) for assessing the quality of nonrandomised studies in meta-analyses.

Wesa KM, Segal NH, Cronin AM, Sjoberg DD, Jacobs GN, Coleton MI, Fleisher M, Dnistrian AM, Saltz LB, Cassileth BR (2015) Serum 25-hydroxy vitamin D and survival in advanced colorectal cancer: aretrospective analysis. Nutr Cancer 67(3): 424-430.

Williams H, Powell IJ, Land SJ, Sakr WA, Hughes MR, Patel NP, Heilbrun LK, Everson RB (2004) Vitamin D receptor gene polymorphisms and disease free survival after radical prostatectomy. Prostate 61(3): 267-275. 
Xiong L, Cheng J, Gao J, Wang J, Liu X, Wang L (2013) Vitamin D receptor genetic variants are associated with chemotherapy response and prognosis in patients with advanced non-small-cell lung cancer. Clin Lung Cancer 14(4): 433-439.

Xu Y, He B, Pan Y, Deng Q, Sun H, Li R, Gao T, Song G, Wang S (2014) Systematic review and meta-analysis on vitamin $\mathrm{D}$ receptor polymorphisms and cancer risk. Tumour Biol 35(5): 4153-4169.

Yagmurdur MC, Atac FB, Uslu N, Ekici Y, Verdi H, Ozdemir BH, Moray G, Haberal M (2009) Clinical importance of vitamin D receptor gene polymorphism in invasive ductal carcinoma. Int Surg 94(4): 304-309.

Yamamoto H, Miyamoto K, Li B, Taketani Y, Kitano M, Inoue Y, Morita K, Pike JW, Takeda E (1999) The caudal-related homeodomain protein Cdx-2 regulates vitamin $D$ receptor gene expression in the small intestine. $J$ Bone Miner Res 14(2): 240-247.

Yao S, Kwan ML, Ergas IJ, Roh JM, Cheng TD, Hong CC, McCann SE, Tang L, Davis W, Liu S, Quesenberry Jr CP, Lee MM, Ambrosone CB, Kushi LH (2016) Association of serum level of vitamin $\mathrm{D}$ at diagnosis with breast cancer survival: a case-cohort analysis in the pathways study. JAMA Oncol; e-pub ahead of print 10 November 2016.

Yiallourou AI, Ekonomou E, Tsamadias V, Nastos K, Karapanos K, Papaconstantinou I, Theodosopoulos T, Contis J, Papalambros E, Voros D, Psychogios J (2014) Association of FokI and PvuII polymorphisms with breast cancer staging and survival among Caucasian women: A prospective study. J BUON 19(3): 633-642.

Yuan C, Qian ZR, Babic A, Morales-Oyarvide V, Rubinson DA, Kraft P, Ng K, Bao Y, Giovannucci EL, Ogino S, Stampfer MJ, Gaziano JM, Sesso HD, Buring JE, Cochrane BB, Chlebowski RT, Snetselaar LG, Manson JE, Fuchs CS, Wolpin BM (2016) Prediagnostic plasma 25-hydroxyvitamin D and pancreatic cancer survival. J Clin Oncol 34(24): 2899-2905.
Zeljic K, Supic G, Radak MS, Jovic N, Kozomara R, Magic Z (2012) Vitamin D receptor, CYP27B1 and CYP24A1 genes polymorphisms association with oral cancer risk and survival. J Oral Pathol Med 41(10): 779-787.

Zgaga L, Theodoratou E, Farrington SM, Din FV, Ooi LY, Glodzik D, Johnston S, Tenesa A, Campbell H, Dunlop MG (2014) Plasma vitamin D concentration influences survival outcome after a diagnosis of colorectal cancer. J Clin Oncol 32(23): 2430-2439.

Zgaga L, Theodoratou E, Farrington SM, Agakov F, Tenesa A, Walker M, Knox S, Wallace AM, Cetnarskyj R, McNeill G, Kyle J, Porteous ME, Dunlop MG, Campbell H (2011) Diet, environmental factors, and lifestyle underlie the high prevalence of vitamin D deficiency in healthy adults in Scotland, and supplementation reduces the proportion that are severely deficient. J Nutr 141(8): 1535-1542.

Zheng W, Wong KE, Zhang Z, Dougherty U, Mustafi R, Kong J, Deb DK, Zheng H, Bissonnette M, Li YC (2012) Inactivation of the vitamin D receptor in $\mathrm{APC}\left({ }_{\min } /+\right)$ mice reveals a critical role for the vitamin $\mathrm{D}$ receptor in intestinal tumor growth. Int J Cancer 130(1): 10-19.

Zhou W, Heist RS, Liu G, Asomaning K, Neuberg DS, Hollis BW, Wain JC, Lynch TJ, Giovannucci E, Su L, Christiani DC (2007) Circulating 25-hydroxyvitamin D levels predict survival in early-stage non-small-cell lung cancer patients. J Clin Oncol 25(5): 479-485.

Zhou W, Heist RS, Liu G, Neuberg DS, Asomaning K, Su L, Wain JC, Lynch TJ, Giovannucci E, Christiani DC (2006) Polymorphisms of vitamin $\mathrm{D}$ receptor and survival in early-stage non-small cell lung cancer patients. Cancer Epidemiol Biomarkers Prev 15(11): 2239-2245.

(c) (i) This work is licensed under the Creative Commons (c) Attribution 4.0 International License. To view a copy of this license, visit http://creativecommons.org/licenses/by/4.0/

(C) The Author(s) named above 2017

Supplementary Information accompanies this paper on British Journal of Cancer website (http://www.nature.com/bjc) 